\title{
FRANKFURTER, LABOR LAW AND THE JUDGE'S FUNCTION
}

\section{GLYDE W. SUMMERS广}

WHEN the first Roosevelt was considering appointing Holmes to the Supreme Court, he wrote to Senator Lodge: "Now I should like to know that Judge Holmes was in entire sympathy with our views . . . absolutely sane and sound on the great national policies for which we stand in public life."1 The second Roosevelt needed to make no such inquiries before appointing a successor to the "Holmes chair." Professor Frankfurter was not only "sane and sound on the great national policies," he was one of the consulting architects in their design. Those who believed that the stultifying conservatism of the Court could be corrected by appointing men of liberal economic and social predilections rightly rejoiced. If his performance on the Court disappointed them, the fault lay not in his past but in their premises.

\section{Personal Convictions and the Judge's Function}

Labor, which had felt the lash of the injunction and the helpless despair of sapped or strangled legislation, now had a new friend on the Court. As a young law professor, Frankfurter had been one of the front-rank fighters for the constitutionality of social legislation. He had helped perfect the "Brandeis brief" which sought to persuade the courts of the reasonableness of the statutes by presenting their factual, social and economic justification. ${ }^{2}$ He helped prepare the briefs and argued before the Supreme Court in the famous cases of Bunting v. Oregon ${ }^{3}$ and Adkins v. Children's Hospital. ${ }^{4}$ His advocacy in these causes went beyond the Holmes aloofness that the legislatures should be allowed to make their own mistakes. He passionately believed in the rightness of the legislation. ${ }^{5}$

†Professor of Law, Yale Law School.

1. Frankfurter, Mr. Justice Holmes and the Supreme Court 22 (1938), reprinted in Frankfurter, Law and Polimics 61, 67 (1939) (hereinafter cited as Law and Politics). Frankfurter is fond of pointing out that shortly after being seated Holmes disappointed Roosevelt's expectations by dissenting against the government in Northern Securities Co. v. United States, 193 U.S. 197, 364 (1904). See 21 Dictionary of AMr. Brography 417, 422 (Supp. One, 1944), reprinted in FRANKFURTER, OF LAW AND MEN 158, 172 (1956) (hereinafter cited as OF LAw A vo MEN). See also Frankfurter, Book Review, 44 Harv. L. REv. 661, 662 (1931).

2. MacLeish, Foreword to Law and Polutres xviii-xix.

3. 243 U.S. 426 (1917). The brief was prepared by Brandeis, Frankfurter and Goldmark. After Brandeis was appointed, Frankfurter argued the case before the Court and won. See note 2 sipra.

4. 261 U.S. 525 (1923).

5. See, e.g., Frankfurter, The Eight-Hour Day, letter to the editor, Boston Herald, Oct. 9, 1916, reprinted in LAw aNd Politics 203. 
Frankfurter was one of the most outspoken critics of the labor injunction. "[T] he use of labor injunctions has, predominantly, been a cumulative influence for discord in our national life. Mounting embitterment in masses of men and women has generated the growing conviction that the powers of the government are perverted by, and in aid of, the employers, and that the courts are the instruments of this partisan policy. ... And the abuse of injunctions in labor cases can be discontinued only by the discontinuance of their use."

When the Arizona anti-injunction statute was declared unconstitutional in Truax v. Corrigan, ${ }^{7}$ he acidly remarked: "For all the regard that the Chief Justice of the United States pays to the facts of industrial life, he might as well have written this opinion as Chief Justice of the Fiji Islands."8 With Nathan Greene he published The Labor Injunction, a classic study of the procedural and substantive evils pervading this method of judicial control. The book served also as a scholarly brief and analysis for a federal anti-injunction statute which was enacted two years later as the Norris-LaGuardia Act.

During the First World War, Frankfurter served as Secretary to the President's Commission on Mediation and Chairman of the War Labor Policies Board. Out of this experience grew a profound conviction that collective bargaining was a necessary correlative of political democracy. In 1920, he wrote:

"Industrial unrest is bound to continue just so long as the present state of mind and feeling of workers is generated by growing disparity between their participation in politics and their exclusion from industrial direction. ... Not until we act on a generous acceptance of the fact that what is at stake is a redistribution of power from the autocratic direction of employers to the responsible participation of all who are involved in industry will we get out of the woods of feud and fury."9

Ten years later, he affirmed his convictions, this time in economic rather than political terms: "Once we recognize that the right of combination by workers is in itself a corollary to the dogma of free competition, as a means of equalizing the factors that determine bargaining power, the consequences of making the power of unions effective will be seen in truer perspective."10 The declaration of policy in the Norris-LaGuardia Act was the flowering of his philosophy and also the seed which germinated in the Wagner Act. Less than four months before being named to the Court, he had written: "Economists and historians are now largely agreed that the resistance to a natural and responsible tradeunionism has been one of the most disturbing factors in our economy."11

6. Frankfurter, Labor Injunctions IInst Go, unsigned editorial, 32 New REPublic 109, 110 (1922), reprinted in LaW aNd Politics 218, 220-21.

7. 257 U.S. 312 (1921).

8. Frankfurter, The Same Mr. Taft, unsigned editorial, 29 NEw REpublic 191, 193 (1922), reprinted in LAw and Politics $41,46$.

9. Frankfurter, Law and Order, 9 YALE REview (n.s.) 225, 229, 232 (1920), reprinted in LaW AND Politics 211, 213, 214.

10. Frankfurter \& Greene, The Labor Injunction 205 (1930).

11. Frankfurter, Mr. Justice Holmes and the Suprease Court 37 (1938), reprinted in LAW AND Politics 61, 75. 
If the deeply held social and economic beliefs of a Justice form the guide lines for his future decisions, organized labor could look forward to a brighter day. Here was an articulate advocate of protective legislation, an emancipator from the injunction and a tested champion of unionization and collective bargaining. This portrayal, however, described but half the man, for social and economic views were only part of his total framework of beliefs. His deeply held convictions of labor's rights were subsidiary to his broadly conceived principals on the proper functioning of our constitutional system. ${ }^{12}$

On at least two occasions, Frankfurter had given notice that where these values conflicted, his interest in labor's rights was outranked by his central concern for a healthy and responsible political democracy. Writing in the New Republic, he shocked some of his single-minded friends with a vigorous defense of the Supreme Court's decision in the Child Labor Tax Case. ${ }^{13}$ " 'Humanity' is not the test of constitutionality. Recognition that a law enacted by Congress seeks to redress monstrous wrongs and to promote the highest good does not dispose of the Supreme Court's duty when the validity of such a law is challenged." The legislation was a "dishonest use of the taxing power" which would "violate the bond of the union." Even more shocking, he opposed the Child Labor Amendment, "because such concentration [in Washington] would be self-defeating in its execution and make for a corresponding paralysis of local responsibility."14 Much as he hated the economic evil, he prized federalism more. After the first Coronado Coal case, ${ }^{15}$ which held unions subject to suit as legal entities, he wrote in defense of the Court's decision, "complete immunity for all conduct is too dangerous an immunity to confer upon any group."16 His disagreement with the prevailing standards used by the courts in determining what union conduct was illegal did not alter his more fundamental belief in imposing legal responsibility on all groups in the community.

Frankfurter did not shed his personal convictions as a worn-out cloak when he donned the judicial robes; they were too much a part of his view of the way the world should work. While they occasionally provide the dominant motives

12. For an analysis of Frankfurter's complex of social and political views at the time he was appointed, see Hamilton, Precieze of a Justice, 48 YALE L.J. 819 (1939).

13. 259 U.S. 20 (1922).

14. Frankfurter, Child Labor and the Court, 31 New Republic 248 (1922), reprinted in LAw AND Politrcs 206. To Frankfurter, the wiser solution was political education at the local level. "The deeper statesmanship may well be not to attempt removal from the remote center of this or that glaring evil, but to awaken the community to the need of its removal, for only by such vigorous civic education will an informed public opinion, essential to the enforcement of decent standards, be secured and sustained." Ibid.

His suggestion on how to achieve local action was that "the League of Women Voters in every state make it the order of the day to put a wise child labor law upon the statute books of every state." He envisioned that, "the states would furnish competition not in child labor, but in child welfare." Ibid.

15. UMW v. Coronado Coal Co., 259 U.S. 344 (1922).

16. Frankfurter, The Coronado Case, $31 \mathrm{NEw}$ Republic 328, 330 (1922). "The question is not whether the union should be responsible for a wrong, but whether certain acts complained of constitute a wrong." Ibid. 
to his opinions, they create not a simple melody but competing themes. In United States v. Hutcheson, his first labor opinion, he used his own NorrisLaGuardia Act to loosen the shackles of the antitrust laws from labor. ${ }^{17} \mathrm{He}$ contradicted his own declaration on the intended reach of the act and repudiated the line of reasoning to which he had subscribed less than one year earlier in Apex Hosiery Co. v. Leader. ${ }^{18}$ Collective bargaining required the combination of workmen. The bludgeoning antitrust laws were clumsy if not mischievously destructive devices that forced the courts to mark the difficult lines limiting the right of workers to combine for their mutual aid and protection. A better course was to sever labor from these laws and let Congress face frankly its responsibility of deciding at precisely what points the cost of competition is too great. Viewing the deeper thrust of the Norris-LaGuardia Act as removing from the courts the function of making labor law, he boldly used his child to do this man's work.

However, giving "hospitable scope" to the act would not be carried to the point of threatening other more basic values. Unions must still live under the law. Thus, in United Brotherhood of Carpenters z. United States, he protested that the majority had misread the Norris-LaGuardia Act and had given unions practical immunity from antitrust liability. ${ }^{19}$ The effect of the decision was to "turn back the clock of legal history a hundred years and disregard the practicalities of collective action by powerful organizations." 20 In United States $v$. $U M W$, his concern for protecting the authority of the courts to decide their own jurisdiction was so dominant that he risked reopening the door to the evils of the temporary injunction. ${ }^{21}$ Even though the act deprived the court of jurisdiction, the union, under pain of criminal contempt, had to follow the legal processes of appeal and obey the void order until it was reversed. ${ }^{22}$ Finally,

17. 312 U.S. 219 (1941).

18. 310 U.S. 469 (1940). In that case the argument was made that Congress intended to exclude activities of labor unions from the operation of the Sherman Act. The majority opinion, in which Frankfurter joined, disposed of this contention by saying: "The long time failure of Congress to alter the Act after it had been judicially construed, and the enactment by Congress of legislation which implicitly recognizes the judicial construction as effective, is persuasive of legislative recognition that the judicial construction is the correct one." Id. at 48S.

In Frankfurter \& Greene, The Labor Injunction 215 (1930), Frankfurter had said: "But the immunity accorded is circumscribed: it is not immunity from legal as distinguished from equitable remedies,--hitherto unlawful conduct remains unlawful . . ." And "all other remedies in federal courts and all remedies in state courts remain available." Id. at 220 .

19. 330 U.S. 395,413 (1947).

20. Id. at 420 . Through this opinion runs the same theme as his comment on the first Coronado Coal case-unions should be governed by the same rule of liability as corporations. Similarly, in United States v. White, 322 U.S. 694 (1944), he joined in a decision holding union officers liable, just as corporate officers, to deliver organization records in . their possession.

21. 330 U.S. 258 (1947).

22. Frankfurter qualified this by saying: "To be sure, an obvious limitation upon a currt cannot be circumvented by a frivolous inquiry into the existence of a power that has 
not even the explicit words of the act, nor the evils of judicial interference in labor relations could bar the courts from enjoining unions when they abused their legal power to represent employees by discriminating against Negroes or other minority groups. ${ }^{23}$

Frankfurter's personal convictions also colored, in perhaps more subtle tones, his opinions in cases involving protective labor legislation. His long battle against the rotting contagion of the sweatshop may be reflected in Gemsco, Inc. v. Walling, where he supported the decision that, under the guise of preventing evasion of wage orders, the administration could flatly prohibit all homework in the embroidery industry even though this action destroyed a traditional method of production which accounted for forty per cent of the entire industry and in spite of congressional refusal to make such power explicit. ${ }^{24}$ However, even this concern is not completely overriding. ${ }^{25}$ In 10 East 40th Street Bldg. v. Callus, he limited the reach of the Wage-Hour Law by adding as a weighty factor the preservation of an area of regulation for the states. ${ }^{26}$ The belief in the proper division of power within a system of federalism may supersede the belief in all-inclusive minimum wage laws. ${ }^{27}$

Although these strong personal convictions which Frankfurter brought to the Court have left their mark, they help but little in understanding his labor

unquestionably been withheld." Id. at $\mathbf{3 1 0}$. However, this qualification still leaves a risky opening for temporary injunctions, for the Court has engrafted a growing number of exceptions on the act, and state courts have read broad exceptions ihto parallel state statutes. Many limitations are not so "obvious" as to make inquiry "frivolous."

23. Graham v. Brotherhood of Locomotive Firemen, 338 U.S. 232 (1949). The NorrisLaGuardia Act has not received favored treatment from Mr. Justice Frankfurter; rather, he has treated it as a disowned child. For sixteen years following Hutcheson, he consistently voted to restrict its scope. In addition to the cases already mentioned, see Brotherhood of R.R. Trainmen v. Chicago R. \& I.R.R., 353 U.S. 30 (1957); Local 33, Bakery Sales Drivers v. Wagshal, 333 U.S. 437 (1948) ; Allen Bradley Co. v. Local 3, Int'l Brotherhood of Elec. Workers, 325 U.S. 797 (1945) ; Hunt v. Crumboch, 325 U.S. 821 (1945) (dissenting opinion); Columbia River Packers Ass'n v. Hinton, 315 U.S. 143 (1942). The only exception was Brotherhood of R.R. Trainmen v. Toledo, P. \& W.R.R., 321 U.S. 50 (1944). Finally, in his last labor opinion, Textile Workers Union v. Lincoln Mills, 353 U.S. 448, 460 (1957), he filed a biting dissent, chiding the unions for making "an ally of an old enemy," because they sought to enforce the arbitration clause of a collective agreement by "resorting to the otherwise much excoriated labor injunction." Id. at 924. He indicated with the casualness of a footnote that the possibility existed that the act barred such equitable relief. $I d$. at 927 n.3.

24. 324 U.S. 244 (1945).

25. Compare his refusal to uphold the exemptions for agricultural workers as defined by the Administrator. Addison v. Holly Hill Fruit Products, Inc., 322 U.S. 607 (1944).

26. 325 U.S. 578 (1945).

27. Frankfurter voted with the majority in Western Union Tel. Co. v. Lenroot, 323 U.S. 490 (1945), which restrictively interpreted the child labor provisions of the Fair Labor Standards Act. This vote may have reflected a residue of his earlier stated beliefs that child labor should be attacked at the local rather than national level. His article on the Child Labor Tax Case, see note 14 supra and accompanying text, is clearly echoed in his dissent in United States v. Kahriger, 345 U.S. 22, 37 (1953), where he protested that the federal gambling tax was an encroachment on reserved state power. 
decisions. These were his views as a citizen advocating social and political measures according to his personal preferences. As a Justice, he no longer speaks as a citizen but as an instrument of the law which expresses a consensus beyond the views of any single citizen. Judicial robes did not change the man but they did change his function, and Mr. Justice Frankfurter is acutely aware of his changed function. ${ }^{28} \mathrm{He}$ is articulately self-conscious that a binding set of values appropriate to that special responsibility has been imposed upon him. "[A] judge worth his salt is in the grip of his function." ${ }^{29}$ The first place in his hierarchy of values, therefore, is granted to those which define the proper role of the Court within our political and social structure. ${ }^{30}$

Mr. Justice Frankfurter's opinions in labor cases constitute no identifiable unit. Such a classification is to him meaningless if not improper, for he does not conceive any unique role for the Court in labor law. His opinions do reflect notions on the structure and purpose of collective bargaining, but these views seldom decide concrete cases. Largely governed by overriding considerations which cut across all fields, his decisions in labor cases are but special manifestations of pervading principles.

To examine the decisions of Mr. Justice Frankfurter-or any other judge worthy of the robe-merely in the light of his political or economic views is to stand a candle in the corner. To attempt to label him prolabor or antilabor is to blow the candle out. The significant study

28. "'Does a man become any different when he puts on a gown?' I say, if he is any good, he does." Frankfurter, Chief Justices I Have Knozen, 39 VA. L. REv. 883, 901 (1953), reprinted in OF LAW AND MEN 101, 133. "If judges want to be preachers, they should dedicate themselves to the pulpit; if judges want to be primary shapers of policy, the legislature is their place. Self-willed judges are the least defensible offenders against government under law." Frankfurter, John Marshall and the Judicial Function, 69 HARv. L. REv. 217, 238 (1955), reprinted in Of Law and Men 3, 29. In Burford v. Sun Oil Co., 319 U.S. 315 (1943), he dissented from a decision which narrowed the diversity jurisdiction of the federal courts: "I speak as one who has long favored the entire abolition of diversity jurisdiction. ... But I must decide this case as a judge and not as a legislative reformer." Id. at 337. Although Frankfurter feels bound to vote as a judge, he still feels free to preach in his opinions. See, e.g., his broadside attack on the whole institution of diversity jurisdiction as a misconceived policy in his concurring opinion in Lumbermen's Mut. Cas. Co. v. Elbert, 348 U.S. 48, 53-60 (1954).

29. Frankfurter, Some Observations on the Nature of the Judicial Process of Supreme Court Litigation, 98 Proceedings, American Philosophical Soctety 233, 238 (1954), reprinted in OF LAW AND MIEN 31, 41. He made even more explicit the subservience of the judge to his conception of his function. "To assume that a lawyer who becomes a judge takes on the bench merely his views on social or economic questions leaves out of account his rooted notions regarding the scope and limits of a judge's authority. The outlook of a lawyer fit to be a Justice regarding the role of a judge cuts across all his personal preferences for this or that social arrangement." Ibid.

30. Shortly before being nominated to the Court, Frankfurter had written: "The conception which a judge has of his own function, and the fastidiousness with which he follows it, will in large measure determine the most delicate controversies before him." FrANKfurter, Mr. Justice Holmes and the Suprene Court 25 (1938), reprinted in Law aNd Politics 61, 69. 
is first, to seek diligently to discover his conception of his role as a member of the Court, and second, to examine critically whether that conception is adequate to our needs. While confining such a study to labor decisions creates risks of distortion, the narrower focus may also make the lines sharper.

\section{The Duty Not To Decide}

No member of the Court invokes more vigorously than Mr. Justice Frankfurter the sheaf of rules which enables it to avoid passing on constitutional issues. Controversial labor cases have suffered from such spurning. For example, in Westinghouse, he explicitly skirted the constitutionality of section 301 of the Taft-Hartley Act by seizing upon a restrictive interpretation which he tacitly recognized had little foundation in logic, legislative history or the practicalities of collective bargaining. ${ }^{31}$ In United States $v$. $U A W$, the union was indicted for using union dues to sponsor television broadcasts urging the election of certain candidates to Congress. ${ }^{32}$ The statute could not be distorted to exclude this conduct, but Frankfurter still refused to "enter upon the delicate process of constitutional adjudication" when it was not "absolutely necessary to a decision." 33 The case could be remanded, and the constitutional issues could await trial.

Rigid adherence to these rules of avoidance does not represent for Frankfurter an evasion of responsibility; for him, a duty exists not to decide constitutional issues unless they are inescapable. The duty measures the role which he believes the Court can and should play within a democratic structure. Determination of constitutionality is delicate, for the issues are often essentially political and come to the Court thinly disguised in legal garb. The cloistered oligarchy which is not answerable to the electorate is asked to judge these issues of policy. Such power should be sparingly used lest it be swept away by outraged popular opinion. ${ }^{34}$

More central to Frankfurter's conception of the Court is his profound distrust of its competence to judge these issues. The training and experience of the Justices, the limitations which litigation places on full exploration of all relevant facts and the episodic and fortuitous presentation of narrow facets in isolated cases disable the Court from making a creative contribution to solution of the

31. Association of Westinghouse Salaried Employees v. Westinghouse Elec. Corp., 348 U.S. 437 (1955). The Court here narrowly construed the federal statute to avoid the constitutional issue. However, the Court may also read into the statute special standards giving affirmative protection to quasi-constitutional rights because otherwise "constitutional questions arise." Stecle v. Louisville \& N.R.R., 323 U.S. 192, 198 (1944).

32. 352 U.S. 567 (1957).

33. Id. at 590 .

34. Frankfurter has been deeply impressed by the chain of events following Dred Scott v. Sandford, 60 U.S. (19 How.) 393 (1857), particularly by the jeopardy in which the decision placed the Court. The constitutional issue could there have been avoided by dealing only with the precise facts of the case. See United States v. UAW, 352 U.S. 567, 590 (1957). 
complex social problems involved. Postponement may gain the time necessary for solution through more appropriate and competent channels. The costs of uncertainty are weighed against the "self-inflicted wounds" suffered by the Court when it has needlessly pronounced on constitutional issues. ${ }^{35}$ "The impressive lesson of history confirms the wisdom of the ... self-imposed inhibition ...."36

Labor cases bear witness to this wisdom. Frankfurter classifies Adkins v. Children's Hospital among the Court's self-inflicted wounds. ${ }^{37}$ Similarly, in United States $v$. Petrillo, ${ }^{38}$ the Court floundered into declaring the Lea Act constitutional on a motion to dismiss the indictment, only to have the district court find after trial that Petrillo had not violated the act. ${ }^{30}$ The mischievous remand of Government and Civic Employees, CIO v. Windsor, on the other hand, may serve to give the Alabama legislature time to recognize that unionization of government employees can serve constructive purposes. ${ }^{40}$

To find that the Court's avoidance of constitutional issues has sometimes been wise does not, however, entirely dispose of the matter. Useful rules may be transformed into self-justifying absolutes. ${ }^{41}$ The only safeguard against petrifaction is a constant attention to the purposes served by the particular rule. Frankfurter never faces the unsettling question whether the reasons for judicial inhibition apply with equal force to all situations. Two cases suggest the problem. In United States v. CIO, the Court confronted one of the most controversial provisions of the Taft-Hartley Act less than one year after its adoption. ${ }^{42}$ Whether unions should be free to make political contributions or

35. The phrase is found in Hughes, The Suprense Court of the United States 50 (1928).

36. United States v. UAW, 352 U.S. 567, 590 (1957). This is Frankfurter's most deeply rooted notion as to the proper functioning of the Court. See, e.g., Frankfurter, The Supreme Court of the United States, 14 Encyclopaedia of Soctal Sciences 474, 475-77 (1934), reprinted in Law and PoLITICs 21, 23-28.

37. See Frankfurter, John Marshall and the Judicial Function, 69 HARv. L. Rev. 217, 235 (1955), reprinted in OF LAW AND MEN 3, 25.

38. 332 U.S. 1 (1947).

39. 75 F. Supp. 176 (N.D. I11. 1948).

40. 77 Sup. Ct. 838 (1957). Where constitutionality of a state statute is involved, the Court insists that the statute first be authoritatively interpreted in the state courts in reference to a concrete fact situation. AFL v. Watson, 327 U.S. 582 (1946); Alabama State Federation of Labor v. McAdory, 325 U.S. 450 (1945). In Windsor, the statute had been interpreted by the state court, but the Court remanded the case because the state court had not been "asked to interpret the statute in light of the constitutional objections . ..." If these arguments had been presented to the state court "it might have construed the statute in a different manner." 77 Sup. $C_{\text {. }}$ at 839 . The plaintiffs must first seek a reinterpretation.

41. This is particularly true where the rules relied upon are merely technical devices to achieve the result and do not reflect the reason for their invocation. Some, but not all, of the rules of avoidance are of this technical nature or are at times technically applied.

42. 335 U.S. 106 (1948). In his concurring opinion, Frankfurter spells out many of the rules which the Court uses in avoiding constitutional issues. He preferred to dispose of the case, not by narrowly construing the statute, but by holding that the constitutional issue was not properly presented because the government had not argued the most effective 
use union funds for political activity was clearly a problem in the domain of public debate. The Court, in avoiding the constitutional issues, in fact projected a compromise, giving unions some freedom which they feared had been eliminated by the statute. Delay served the constructive purpose of allowing time for the parties to make their own accommodation. Unions could experiment with a program of public discussion of general issues, energetic campaigning among members and voluntary contributions for candidates. This program might fulfill their needs and capacities and also be tolerable to those who looked askance at union political action. Furthermore, the Court might gain time to see the broad implications of the problem, to learn of variations in union activity and to project new compromises. The solution nearly succeeded, and the ten intervening years have cast new light on the complex problem. After the Petrillo embarrassment, the Court's avoidance of this constitutional issue in United States v. UAW until after trial was understandable. ${ }^{43}$ Even though no dispute exists about the facts on which an indictment is based, trial of the case may produce a broad picture of the whole pattern of union practices and other relevant facts that will be extremely helpful to the Court in making its ultimate determination.

In contrast stands the Westinghouse case. No substantial political issue was posed here, for few seriously contended in 1954 that employers or unions should not be legally responsible under collective agreements. The constitutional problem was the jurisdiction of the federal courts. The question was legal, not political -and the Court was the most competent of all agencies of government to solve it. The Court refused to exercise its competence, not by creating a bearable compromise but by cleaving the collective contract in two. It did not encourage accommodation but compelled confusion. ${ }^{44}$ The day of reckoning could only be postponed, and in the meantime a disruptive dichotomy was injected into the law of collective agreements. Even after the constitutional

grounds for supporting the statute, nor had the defendants urged a construction of the statute that would have secured their rights without declaring it unconstitutional. Id. at 124-29.

43. In both United States v. CIO and United States v. UAW, Frankfurter pointedly cited the Petrillo case and the subsequent dismissal of the indictment. He seemed resolved not to make the same mistake again. Subsequent events have proved the wisdom of his position. At trial, UAW's evidence described a broad program of education in public affairs directed largely toward its members. The presentation of candidates prior to election was only incidental to the year-round program. At the end of the trial, the jury acquitted the union. N.Y. Times, Nov. 7, 1957, p. 1, col. 4.

44. Frankfurter interpreted $\S 301$ as not authorizing a union to enforce in the federal courts the "employer's failure to comply with terms of a collective agreement relating to compensation, terms peculiar in the individual benefit which is their subject matter and which, when violated, give a cause of action to the individual employee." 348 U.S. at 460 . The confusion which this created is suggested by UEW v. General Elec. Co., 231 F.2d 259 (D.C. Cir. 1956) ; United Steel Workers v. Galland-Henning Mfg. Co., 241 F.2d 323 (7th Cir. 1957) ; ILGWU v. Jay-Ann Co., 228 F.2d 632 (5th Cir. 1956); Burlesque Artists Ass'n v. I. Hirst Enterprises, 134 F. Supp. 203 (E.D. Pa. 1955). 
issue is settled, this scar may remain.45 All the Court has gained by delay is guidance from some of their more rational brethren on the circuit courts. ${ }^{46}$

Black v. Cutter Laboratories suggests another factor which may question rigid application of the rules of avoidance. ${ }^{47}$ The California supreme court refused to enforce the award of an arbitrator ordering reinstatement of a worker who was a communist; to enforce her contract rights, the court felt, would violate public policy. The Supreme Court ignored the clear import of the opinion, carefully read excerpts out of context, discovered separate state grounds for the decision and held that it would therefore not decide the constitutional issue. Encroachments on personal freedoms spread spores for further intolerance. Delay may only make the Court's task more difficult; for its silence might encourage further encroachments and thereby create a more hostile climate for its ultimate decision. True the California supreme court may retreat from its position, but can the Supreme Court of the United States afford not to speak in the face of such a position ? $^{48}$

Avoidance of constitutional issues is a cautionary guide drawn from the lessons of history, but it imposes a price. The balance of gains and losses is not identical in all cases but shifts radically depending on the kind of issue involved and the method used to avoid it. Frankfurter would lump all cases together, strike a general average from the course of history and impose on

45. Textile Workers Union v. Lincoln Mills, 353 U.S. 448 (1957), left open the question whether the cleavage continues. Its ultimate resolution may depend on whether Frankfurter, once the constitutional issue is settled, will interpret $\$ 301$ differently; he indicated in Westinghouse that he might be disposed to take this course, if no constitutional questions were involved.

46. See, e.g., the thorough analysis of the problems by Judge Magruder in Local 205, United Elec. Workers v. General Elec. Co., 233 F.2d 85 (1st Cir. 1956); Local 25, Teamsters Union, AFL v. W. L. Mead, Inc., 230 F.2d 576 (1st Cir. 1956). The Court also obtained helpful analyses in law review articles. See Mendelsohn, Enforceability of Arbitration Agreements Under Taft-Hartley Section 301, 66 YaLE L.J. 167 (1956) ; Wollett \& Wellington, Federalimm and Breach of the Labor Agreement, 7 STAN. L. REv. 445 (1956).

47. 351 U.S. 292 (1956).

48. Compare United States v. Rumely, 345 U.S. 41 (1953), where Frankfurter carefully avoided making any statements about what, if any, constitutional restrictions limited the power of congressional investigating committees by construing the committee's empowering resolution with mutilating narrowness. Considerations of the first magnitude suggested avoidance, for this was a uniquely political problem directly subject to political checks. However, countervailing demands were also present. The right of organizations to distribute political tracts and to influence public opinion was involved, and this right was subject to continued jeopardy by other more aggressive committees. Postponement until 1957 of any pronouncement on this problem was not without serious costs, not all of which may yet be clear.

Delay may bring the problem before a different court and produce a different result. Members of the Court who foresee an undesirable result if the constitutional issue is raised may seek postponement to a later and possibly more favorable time. This is to convert the rules of avoidance into manipulative devices for the purpose of effecting personal preferences by subterfuge. 
the Court unbending rules. The Court is not left free to weigh the gains and losses case by case but is bound by mechanical rules of judicial self-restraint.

\section{Deference to Legislative Judgurent}

Mr. Justice Frankfurter's central concept that the Court has limited competence in the political and social sphere makes its heaviest impact when acts of the legislature are challenged. The Court must have, "above all, the humility not to set up its own judgment against the conscientious efforts of those whose primary duty it is to govern." 49

His deference to the legislative branch is well known, but that it grew directly from his first-hand experience in preparing and arguing labor cases before the Court is not so well known. In 1912, before he became an understudy to Brandeis, he recognized that the Court in determining the constitutionality of minimum wage or maximum hour laws was making a social not a legal judgment. However, he argued not for judicial abdication but for judicial enlightenment. He saw the Brandeis brief as a device enabling the Court to give "due regard to the facts which induced the legislation." "so Such a judicial approach would leave "still unimpaired the benefits of the reviewing power of the judiciary in our governmental system, for the reflex action of the existence of this power on the part of the courts to set aside legislation restrains unwise legislative action and induces the scientific attitude of basing legislation only upon adequately ascertained facts." 51

When, however, the Taft Court "veered toward a narrow conception of the Constitution,"52 he began to re-examine his premises. In 1921, the Court declared the Arizona anti-injunction act invalid as a taking of property and denial of equal protection of the laws. ${ }^{53}$ This decision, declared Frankfurter, is "fraught with more evil than any which it has rendered in a generation. It challenges the whole scope of judicial review under the Fifth and Fourteenth Amendments."54 In 1923, Frankfurter argued and lost Adkins v. Children's Hospital, a decision which blotted out fifteen years of judicial enlightenment. His disillusionment destroyed any confidence in "the benefits of the reviewing

49. Frankfurter, Social Issues Before the Supreme Court, 22 Yale Review (n.s.) 476, 486 (1933), reprinted in Law and Politics 48, 52-53.

50. Frankfurter, The Zeitgeist and the Judiciary, 29 SURvEY 542, 543 (1933), reprinted in LAW AND PoLITICS 3, 4.

51. Id. at 544, LAw AND Polimics at 9. This was written after Brandeis's signal victory in Muller v. Oregon, 208 U.S. 412 (1908), and during a period of relative judicial tolerance. Subsequent victories in Stettler v. O'Hara, 243 U.S. 629 (1917), and Bunting v. Oregon, 243 U.S. 426 (1917), gave continued confidence that the Court could provide a healthy check on unwise legislative action without hampering needed social reforms.

52. Frankfurter, The Supreme Court of the United States, 14 ENCYCLOPAEDIA of THE Social Sciences 474, 477 (1934), reprinted in Law and Politics 21, 27.

53. Truax v. Corrigan, 257 U.S. 312 (1921).

54. Frankfurter, The Sante Mr. Taft, unsigned editorial, 29 New Republx 191, 192 (1922), reprinted in LAw and Politics 41, 44.

55. 261 U.S. 525 (1923). 
power ... to set aside ... unwise legislative action."56 In 1924, he wrote, "no nine men are wise enough and good enough to be entrusted with the power which the unlimited provisions of the due process clauses confer. ... The due process clauses ought to go."s7

This deep distrust of the Court's competence was repeatedly reinforced by later labor cases. In 1938, looking back, he pointed to the social evils suffered because the Constitution had been "used as an obstruction to the healthy development of trade-unionism" by voiding legislation protecting the right of association. "One can only surmise," he said, "what would have been the gain to social peace and economic security had the dissenting views expressed more than twenty years ago by Mr. Justice Holmes been the Court's views ....." "s8

Ironically, all of these battles had been won by the time he reached the Court. As Felix Cohen observed, "one may wonder what there is left for Mr. Frankfurter to contribute to a court and a body of law that have already accepted his chief teaching."59 Even more ironically, distrust of the Court's competence, Frankfurter's central concept born out of antilabor decisions, received one of its most articulate statements in an opinion upholding a state law prohibiting all forms of union security agreements. ${ }^{80}$ The concept caused him to be termed a liberal at the time of his appointment; his extension of it on the Court has exposed him to criticism as a conservative.

The reasoning with which Frankfurter has girded his distrust of judicial power and deference to legislative judgment is reflected in the arguments which he marshals in AFL v. American Sash \& Door Co. ${ }^{61}$ They carry logically not only to the conclusion that the due process clause must go, but reach far beyond, almost to the brink of repudiating all judicial review of legislative action. ${ }^{62}$ Although he there overstates his position, he clearly reveals how deep-running this current is in his judicial philosophy. ${ }^{63}$

56. Frankfurter, The Zeitgeist and the Judiciary, 29 SuRvey 542, 544 (1933), reprinted in LAW AND Politics 3, 9.

57. Frankfurter, The Red Terror of Judicial Reform, unsigned editorial, 40 NEw REpublic 110, 113 (1924), reprinted in Law and Polmtics 10, 16.

58. Frankfurter, Mr. Justice Holmes and the Supreme Court 38 (1938), reprinted in LAW AND PoLitics 61, 76.

59. Cohen, Book Review of Law and Politics, 101 New Republic 145 (1939). State and federal anti-injunction legislation had been upheld. Senn v. Tile Layers Union, 301 U.S. 468 (1937) ; Lauf v. E. G. Shinner \& Co., 303 U.S. 323 (1938). Minimum wage legislation had been sustained. West Coast Hotel Co. v. Parrish, 300 U.S. 379 (1937). And statutory protection of unionization including proscription of yellow dog contracts had been validated. NLRB v. Jones \& Laughlin Steel Corp., 301 U.S. 1 (1937). Frankfurter shared only in upholding the Fair Labor Standards Act. United States v. Darby, 312 U.S. 100 (1941).

60. AFL v. American Sash \& Door Co., 335 U.S. 538 (1949).

61. Ibid.

62. Frankfurter does not expressly repudiate substantive due process, but he emphasizes (1) "the function of legislating is for legislatures who have also taken oaths to support the Constitution"; (2) "the powers exercised by this Court are inherently oligarchic"; 
The legislature shall have its way-unless it tramples on some value which he believes has deep roots or recognition in our history and is fundamental to our way of life. Thus, in Goesaert $v$. Cleary, ${ }^{64}$ he sustained a whimiscally contrived Michigan statute restricting the employment of barmaids, even though the legislation had no factually supported basis other than an "unchivalrous desire of male bartenders .. . . to monopolize the calling." Discrimination on the basis of sex was not invidious if the state asserted "an entertainable belief" that the measure met a "moral and social problem."6r On the other hand, the Taft-Hartley noncommunist affidavit went too far. Although Congress could bar statutory protection to unions whose officers were members of the Communist Party, the statute required an oath on beliefs so broadly worded as to "probe into opinions," an interrogation which "invades the inner life of men." Such violation of the "citadel of his person" is unconstitutional because it "involves surrender of freedoms which exceeds what may fairly be exacted." No attempt is made in either case to articulate a rational standard or to demonstrate factually that the statute violated our deeply rooted tra-

(3) "the judiciary is prone to misconceive the public good . . . and such misconceptions are not subject to legitimate displacement ... except at too slow a pace"; (4) if a democracy "is alert-and without alertness by the people there can be no enduring democracy-unwise or unfair legislation can readily be removed from the statute books." He then grudgingly admits that judicial review is "now too much a part of our constitutional system to be brought into question."

In defining the standard to be applied he says: "Courts can fulfill their responsibility in a democratic society only to the extent they succeed in shaping their judgments by rational standards, and rational standards are both impersonal and communicable. Matters of policy, however, are by definition matters which demand the resolution of conflicts of value, and the elements of conflicting values are largely imponderable. Assessment of their competing worth involves differences of feeling; it is also an exercise in prophecy." Id. at 555-57.

63. A strong clue to Frankfurter's concept of the Court's function is given when he suggests that the reasoning of Marbury v. Madison "is not impeccable and its conclusion, however wise, not inevitable." Frankfurter, John Marshall and the Judicial Function, 69 HARv. L. Rev. 217, 219 (1955), reprinted in OF LAw aNd MEN 3, 5. In his opinions, one catches a note of awkwardness and embarrassment that the Court has been saddled with this inappropriate function. See, e.g., his concurring opinion in Sweezy v. New Hampshire, 354 U.S. 234, 255 (1957).

64. 335 U.S. 464 (1948).

65. Id. at 466-67. He did not object to a Louisiana statute which effectively barred anyone from becoming a harbor pilot except sons of present pilots. This legally enforced nepotism was justified by the "context of the historical evolution of the laws and institution of pilotage." Kotch v. Board of River Port Pilot Comm'rs, 330 U.S. 552, 557 (1947). In light of his strong hostility to other discriminatory practices, Frankfurter's vote here is explainable only on the extreme uniqueness of pilotage work and traditions.

66. American Communications Ass'n v. Douds, 339 U.S. 382, 419-22 (1950) (concurring opinion). The underlying value involved here is one Frankfurter prizes most highly-the right of privacy. The breadth and weight he gives to this value is evidenced in his opinions in United States v. Witkovitch, 353 U.S. 194 (1957); On Lee v. United States, 343 U.S. 747, 758 (1952) (dissenting opinion); Sibbach v. Wilson \& Co., 312 U.S. 1, 16 (1941) (dissenting opinion). He rebels against the ever-encroaching hucksters 
ditions. When the opinion is stripped of verbiage, he thinks it so because he thinks it so.

Mr. Justice Frankfurter does not attempt to distinguish between these cases on the ground that the Court has a special function in protecting against legislative encroachments on personal freedoms. On the contrary, he has explicitly rejected such a distinction. There are no preferred freedoms. "How best to reconcile competing interests is the business of legislatures... to be respected unless outside the pale of fair judgment." 67 This rejection of the preferred freedoms doctrine may have resulted from a gradual process during his first ten years on the Court. In 1938, he wrote:

"Naturally, therefore, Mr. Justice Holmes attributed very different significance to those liberties of the individual which history has attested as the indispensable of a free society from that which he attached to liberties which derived merely from shifting economic arrangements. . . . Because these civil liberties were explicitly safeguarded in the Constitution, or conceived to be basic to any notion of the liberty guaranteed by the Fourteenth Amendment, Mr. Justice Holmes was far more ready to find legislative invasion in this field than in the area of debatable economic reform." 08

His Barnette dissent, in 1943, stated in most forceful terms the Court's oligarchic character and its narrow function in striking down acts of the legislature which was answerable to majority will. Yet he betrayed a willingness to give special protection within the limited scope of free speech.

"All channels of affirmative free expression are open to both children and parents. Had we before us any act of the state putting the slightest curbs upon such free expression, I should not lag behind any member of this Court in striking down such an invasion of the right to freedom of thought and freedom of speech protected by the Constitution."'69

As late as 1949, in sustaining "right-to-work" laws, he could say: "For these are not matters, like censorship of the press or separation of Church and State, on which history, through the Constitution, speaks so decisively

and electronic invasions which penetrate the walls of silence and solitude. See PUC v. Pollak, 343 U.S. 451, 466 (1952) (explanation for not voting); Radio Corp. v. United States, 341 U.S. 412, 421 (1951) (in dubitante opinion).

67. Dennis v. United States, 341 U.S. 494, 539-40 (1951).

68. Frankfurter, Mr. Justice Holmes and the Suprenie Court 51 (1938). In the last piece he wrote before being nominated to the Court, Frankfurter answered friendly critics of Cardozo who suggested that he "viewed encroachments upon civil liberties with less deference to the legislative judgment than that which he accorded economic measures." Frankfurter said that the same was said about Holmes and that the answer applied also to Cardozo. He then requoted' in full his interpretation of Holmes's philosophy. Frankfurter, Mr. Justice Cardozo and Public Law, 48 YaLE L.J. 458, $479-80$ n.47 (1939), 39 Colum. L. Rev. 88, 109-10 n.47 (1939), 52 HARv. L. Rev. 440, $461-62$ n.47 (1939), reprinted in Law and Politics 88, 97-98 n.2.

69. West Virginia State Bd. of Educ. v. Barnette, 319 U.S. 624, 664 (1943) (dissenting opinion). 
as to forbid legislative experimentation."70 Not until the Dennis opinion did he finally reject free speech as subject to special judicial protection. ${ }^{71}$

This development makes more understandable his opinions in the picketing cases. In 1940, he joined in the sweeping pronouncements of Thornhill $v$. Alabama. ${ }^{72}$ The following year, in AFL v. Swing, he held that a state could not ban organizational picketing to protect the economic interests of an employer on the ground that no dispute existed between the employer and his employees. ${ }^{73}$ Traces of the special protection theory for free speech could be seen: "[A]s we have frequently indicated, that right is to be guarded with a jealous eye...."74 On the same day, in Milk Wagon Drivers Union v. Meadowmoar Dairies, Inc., he spoke of the "generous scope which must be given to free speech," and asserted: "Freedom of speech and freedom of press cannot be too often invoked as basic to our scheme of society."75 Ritter revealed some weakening, but the case involved only the power of the state "to confine the sphere of communication" in a geographical sense. ${ }^{76}$

By 1950, the break was nearly complete. ${ }^{77}$ In Hanke, there was no talk of "generous scope" or "guarding with a jealous eye";78 the language was indistinguishable from $A F L$ v. American Sash \& Door. The union had picketed self-employed car dealers because they refused to follow the union's

70. AFL v. American Sash \& Door Co., 335 U.S. 538, 550 (1949) (concurring opinion).

71. Dennis v. United States, 341 U.S. 494, 526-27 (1951) (dissenting opinion). His concurring opinion in Kovacs v. Cooper, 336 U.S. 77, 89 (1949), made a broadside attack on use by the Court of formulae such as "preferred freedom" or "presumptive invalidity." This opinion might be considered a final rejection of any notion that the Court's function is any different where free speech has been curtailed. However, it is evident that Frankfurter saw regulation of sound trucks as a clash between the right of a noisy group to invade the privacy of unwilling listeners and the right of society to "serenity and reflection" without which "freedom of thought becomes a mocking phrase." Id. at 97. In this clash between two aspects of freedom of thought, the legislature could choose-and here its choice was probably the same as Frankfurter's. In Dennis, the clash of interests was not the same, the content of the speech was condemned, and Frankfurter expresses his misgiving as to the wisdom of the legislation. See 341 U.S. at 553-56.

72. 310 U.S. 88 (1940). In his earlier writings, Frankfurter had suggested that labor injunctions invaded freedom of speech, press and assembly. It is not clear from the context what particular union activities he had in mind when he used this language, but picketing would seem included. See Frankfurter, The Labor Injunction, 8 Encyclopaedi of THE Social Sciences 653 (1932), reprinted in Law and Politics 222; Frankfurter, Labor Injunctions Must Go, 32 New Republic 109 (1922), reprinted in Law and Politics 218.

73. 312 U.S. 321. (1941).

74. Id. at 325. For this proposition, he cited Herndon v. Lowry, 301 U.S. 242 (1937); Schneider v. State, 308 U.S. 147 (1939); and the famous footnote in United States v. Carolene Products Co., 304 U.S. 144, 152 n.4 (1938). These were treated as the source of the "preferred freedom" notion in his Kovacs and Dennis opinions.

75. 312 U.S. 287, 299 (1941).

76. Carpenters Union v. Ritter's Cafe, 315 U.S. 722, 727 (1942).

77. For Frankfurter, the decisive reconsideration of the free speech picketing problem came in Giboney v. Empire Storage \& Ice Co., 336 U.S. 490 (1949). See International Brotherhood of Teamsters v. Vogt, Inc., 354 U.S. 284, 291 (1957).

78. International Brotherhood of Teamsters v. Hanke, 339 U.S. 470 (1950). 
rules on closing hours. The state could conclude, ruled Frankfurter, that it was more important to protect self-employers than to allow communication of the facts of the dispute through picketing. The Court would not deny the state the power to strike this balance. "The clash of fact and opinion should be resolved by the democratic process and not by the judicial sword."79

This line of analysis reveals the futility of any attempt to reconcile his opinions on picketing; his premises have shifted. The tour de force in International Brotherhood of Teansters v. Vogt, Inc. traces a jagged line of precedent based on the facts of each case but is less an explanation than a retrospective rationalization. ${ }^{\mathrm{s}}$ More significantly, Mr. Justice Frankfurter's present position renders fruitless discussion whether picketing is free speech, for the Court's function is the same regardless of what social values clash. Picketing is a form of communication, but its social value is of no different order than that which a state may find in protecting small business. The exact proportions of speech, economic pressure, or coercion need not be analyzed or measured by the Court. The test is still the broad, indefinable one of due process applicable to all forms of regulation, speech or otherwise. ${ }^{81}$ Furthermore, to Frankfurter the right to picket is clearly not one of our deeply rooted traditions; he will defer to legislative judgment as to when it should be curbed. ${ }^{82}$

What emerges as Mr. Justice Frankfurter's dominant conception of the Court's role in a democracy is both pervasive and rigid. The Court's function in reviewing legislative acts is the same regardless of time or place or subject matter. If the premise be accepted that ours is and ought to be a government of unfettered majority rule, rigid judicial abstinence is required. This premise, however, is contrary to history and unproven by experience. Our constitutional system assumes, and Frankfurter does not deny, that the judiciary must maintain some constitutional fetters on the legislature. In bold terms, we do not have unlimited trust in majorities. The nondemocratic organ of government must provide safeguards from gross legislative excesses. The function

79. Id. at 478. In Hughes v. Superior Court, 339 U.S. 460 (1950), Frankfurter had held that whether the state policy was expressed by the judiciary or legislative branch was immaterial. Distribution of powers of government was for the state to decide. He does not face openly the question whether a policy so determined had any roots in the democratic process so as to justify deference by the Supreme Court. The deference is here based on values rooted in federalism rather than majority will.

80. 354 U.S. $284,287-93$ (1957). One may hazard a guess that if he were writing on a clean slate, Swing would now come out differently.

81. If Frankfurter's opinions are confused in this field, he has more justification than those who, like Douglas, assert that "picketing has aspects which make it more than speech" without providing any guide or analysis as to what the "more" may be or the different variations in which the "it" may occur.

82. He has recently characterized picketing as "the weapon of strikes" and intermixed without distinction the constitutional position of strikes and picketing. Frankfurter, John Marshall and the Judicial Function, 69 HARv. L. REv. 217, 231 (1955), reprinted in OF LAW AND MIEN 3, 21. 
of the Court varies according to the danger of irresponsible majority rule, and this danger varies in infinite patterns. The dangers to a democracy posed by invasion of freedom of speech and invasion of contract are not of the same order. Denial of the right to vote and denial of the right to practice a particular profession do not create equal threats to the democratic process. Classifications based on race may be more suspect than classifications based on sex, if for no other reason than that of relative political weakness. Religious minorities may be more commonly victimized by intolerant majorities than are economic minorities. ${ }^{83}$

These varied needs tend to be obscured by Frankfurter's rigid concept which asserts that the Court's function is the same in all cases. If judicial review is to fulfill its purpose, the Court must assess at each point the dangers that democratic processes will go astray and then adjust its level of review to meet that danger. Furthermore, the critical danger points are not permanently fixed, but may shift from one period of history to another. There may be no enduring standards for the Court which are equally valid for all time. Upon each judge may be cast the awesome responsibility of measuring correctly the necessities of his time.

\section{Giving Meaning to Legislative Words}

Most labor cases coming before the Court involve statutory not constitutional questions. In these cases, the basic premise-that the primary lawmaking agency in a democracy is the legislature-provides little more than an inner sense of obligation or a frame of reference. It may prevent judicial willfulness in rewriting statutes, but it will not guide the Court to the elusive legislative will.

Believing that he should neither legislate nor frustrate legislation, Mr. Justice Frankfurter is torn by conflicting compulsions. On the one hand, his logic constrains him not to go beyond the words of the statute. "[T] he function in construing a statute is to ascertain the meaning of words used by the legislature. To go beyond it is to usurp a power which our democracy has lodged in its elected legislature." 84 The Court is but a "translator of another's command." 85 It is neither to add to nor subtract from the explicit words any more "than is called for by the shorthand nature of language." 80 This mechanistic description of the judge's role is reinforced by two motivations that permeate much of his thinking. First, the judge's role should be limited,

83. This does not imply neat categories that can be labelled "preferred" or to which "presumptions" can be mechanically attached. It suggests only that the Court in exercising its veto power keep in mind the justification for that power. The approach may be confining, but within the confines exists a constructive responsibility. The judge would have no wider freedom in writing his private notions into fundamental law than under Frankfurter's standardless standards.

84. Frankfurter, Some Reflections on the Reading of Statutes 13 (1947).

85. Id. at 14 .

86. Id. at 16 . 
to protect against willful judges who lack humility and self-restraint. ${ }^{87}$ Second, the Courts should not act as a cleanup crew for sloppy legislators but should increase the pressure on them to discharge their responsibilities. ${ }^{88}$ These formulations and considerations tend to shrink the Court's vision to the words of the statute itself. 89 The wider the view to "context" or "purpose" or "intent," the more evidence the judicial libertine can find to justify his willed result. To find meaning outside the words relieves Congress of pressure to state its will as precisely as possible.

On the other hand, Frankfurter's practical sense reminds him that such narrowness frustrates congressional purpose; for the legislative process is imperfect, and statutory language is inevitably deficient..$^{90}$ This is particularly true of labor legislation, which is characteristically skeletal and experimental. ${ }^{01}$ Often, Congress has unwittingly or deliberately failed to decide the more complicated or more contentious problems. The Court cannot interpret, it must construct; its function is not to translate but create. Thus, Frankfurter speaks of the judge as "selected by society to give meaning to what the legislature has done...."

The labor cases reveal Frankfurter not as a translator but as a creator who does not confine himself either to the words of the statute or the minds of the legislators. Some samples give more flavor than any generalizations. In

87. Thus, Frankfurter objected to Hand's description of statutory interpretation as "proliferation of purpose" because "it might justify interpretations by judicial libertines, not merely judicial libertarians." $I d$. at 8.

88. "In a democracy the legislative impulse and its expression should come from those popularly chosen to legislate and equipped to devise policy, as courts are not. The pressure on legislatures to discharge their responsibility with care, understanding and imagination should be stiffened, not relaxed. Above all, they must not be encouraged in irresponsible or undisciplined use of language." Id. at 29.

89. For two such narrowly written opinions see Addison v. Holly Hill Fruit Products, Inc., 322 U.S. 607 (1944), and Amalgamated Clothing Workers v. Richman Bros., 348 U.S. 511 (1955). However, in spite of his strong language when speaking generally, Frankfurter seldom confines himself to the bare words of the statute.

90. "A statute is an instrument of government partaking of its practical purposes but also of its infirmities and limitations, of its awkward and groping efforts. . . Moreover, government sometimes solves problems by shelving them temporarily. The legislative process reflects that attitude. Statutes as well as constitutional provisions at times embody purposeful ambiguity or are expressed with a generality for future unfolding." FrankFURTER, Sone Reflections on the Reading of Statutes 6-7 (1947). This lecture of Frankfurter's is shot through with the conflict between the theoretically restricted function of the courts and the practical necessities of carrying on government with a limping legislative process. This conflict he neither expressly admits nor resolves.

91. The Fair Labor Standards Act was but a first groping effort to regulate a myriad of complex situations. After fifteen years of experience, more precise provisions helped clarify and crystallize the law as to some of the more troublesome problems. The Wagner Act went little beyond a declaration of rights stated with the terseness of a constitutional document. After ten years, the Taft-Hartley Act embarked on a new experiment, creating more ambiguities than it resolved.

92. Frankfurter, Some Reflections on the Reading of Statutes 8 (1947). 
Phelps Dodge Corp. v. NLRB, the Court had to decide whether an employer, who had refused to hire men because of union membership, could be compelled to employ them and give them back pay.93 Frankfurter looked to the broad purpose of the Wagner Act to encourage collective bargaining; he looked to employer practices that had led to the passage of the act, including the notorious blacklists; and he found that discrimination at the point of hire was as destructive of the purpose of the statute as discrimination after hiring. The forceful thrust of his argument and his skillful manipulation of statutory words ${ }^{94}$ obscure the technique-his statement of the purpose of the act had swept all other considerations before it. The drafters of the statute, acutely conscious of the traditional reluctance of courts to compel performance of personal service contracts, had dared to make explicit only a single provision: employers could be compelled to retain old employees. ${ }^{.5}$ Frankfurter used the momentum of purpose to carry the conclusion a step further: workers with whom the employer had never entered into the employment relationship could be protected.

His method may at times be even bolder. When the Court was faced with the question whether section 8 (d) of Taft-Hartley barred a union from striking at the reopening period of the contract, he did not belabor either the statutory words or legislative intent. ${ }^{96}$ The provision was obviously ambiguous; Congress had never even considered the problem. ${ }^{97}$ Frankfurter looked to the practical consequences of each alternative. To hold that the strike violated 8 (d) was to deny the union any recourse to economic force on reopening-a result which seemed to him incongruous with collective bargaining. ${ }^{98}$ More significantly, he gave great weight to a proposal made by Senator

93. 313 U.S. 177 (1941).

94. The troublesome phrase, "including reinstatement ... with or without back pay" became merely an "illustrative application" of the "versatile principle" that the Board could order such affirmative action as would "effectuate the policies of the Act." Id. at 189.

95. The drafters apparently were afraid that if nothing were said about compelling employment, the courts would say that such a radically new remedy was not implied in the general phrase, "effectuate the policies of the Act." On the other hand, if they explicitly provided that employers could be compelled to employ workers never employed previously, the provision would be challenged by Congress. They carefully chose their words, made explicit but half and with Frankfurter's help obtained the whole.

96. NLRB v. Lion Oil Co., 352 U.S. 282, 294 (1957) (concurring in part).

97. He indicated the ambiguity by pointing out four distinct interpretations which had been suggested by various members of the Board and the lower federal courts, none of which had gained general acceptance. Id. at 297.

98. Nothing, of course, prevents the parties from expressly providing in their contract that there shall be no recourse to economic force at reopening. Such a provision would then bring to bear both $\S 8(\mathrm{~d})$ and $\S 301$. Thus, the character of the reapening is left to the bargaining process. In United Brotherhood of Carpenters v. United States, 330 U.S. 395, 413 (1947) (dissenting opinion), Frankfurter looked past the explicit words of the Norris-LaGuardia Act, reviewed the whole history of union liability for acts of its members and officers and laid great emphasis on the practical consequences of the majority opinion. All of these were skillfully interwoven to screen the troublesome statutory language. 
Taft and the Joint Committee on Labor Management Relations two years after the passage of the act.99 This subsequent solution, never passed by Congress, was recommended to the Court by Frankfurter to be written by judicial decision into the act.

The creative function was used to a somewhat different end in Uniled States v. UAW.100 Here Frankfurter viewed section 302; he considered its restrictions upon political expenditures in historical perspective and traced the long line of legislation controlling political contributions and expenditures both by individuals and corporations. The fears and ideals flowing through the debates for over fifty years were laid bare, and this section was revealed as another step in an unfolding process of avoiding "the deleterious influences on federal elections resulting from the use of money by those who exercise control over large aggregations of capital."101 He did not add to the reach of the statute, for the same result might well have been reached by a process of logical deduction from the bare words. His contribution was that of examination beyond the words to unearth the policy in its historical depth. He did not interpret according to the mind of the Eightieth Congress; many of its members would be helpfully enlightened by reading the opinion. In the very best sense, this is "to give meaning to what Congress has done."102

These examples suggest the depth and breadth of Frankfurter's approach. He looks to the historical line of development, the needs out of which the statute grew and even to subsequent events and present practical needs-in short, to the whole legal and social environment of a statute. In his own ambiguous words, "nothing that is logically relevant should be excluded."103 Clearly, he goes beyond the minds of the men who drafted or enacted the statute. He patches, enlarges and fulfills their awkward product.

Frankfurter includes within the context for interpretation values which he considers so basic to our scheme of government, legal pattern or moral sense that Congress should be presumed to have them in mind. ${ }^{104}$ In Kirschbaum Co. $v$. Walling, the concern for preserving state power was overtly weighed in determining the reach of the Fair Labor Standards Act: "[T]he underlying assumptions of our dual form of government ... cut across what might other-

99. NLRB v. Lion Oil Co., 352 U.S. 282, 299-300 (1957). In United States v. UMW, 330 U.S. 258, 307 (1947) (concurring opinion), he was faced with a statutory gap in the Norris-LaGuardia Act created by the subsequent use of the seizure device. To reinforce his conclusion, he looked to congressional debates ten years later which involved the War Labor Disputes Act.

100. 352 U.S. 567 (1957).

101. Id. at 585 .

102. See text at notes $92-94$ supra.

103. Frankfurter, Some Reflections on the Reading of Statutes 23 (1947).

104. See id. at 21-22. Manifestations of this run through his opinions. See, e.g., United States v. Witkovitch, 353 U.S. 194 (1957) ; United States v. Minker, 350 U.S. 179 (1956) ; Eichenlaub v. Shaughnessy, 338 U.S. 521, 533 (1950) (dissenting opinion). 
4

wise be the implied range of the legislation." 105 Similarly, the Court wrote into the Railway Labor Act an implied obligation on the majority union not to discriminate in its bargaining, ${ }^{106}$ and even the express words of the NorrisLaGuardia Act were overridden by this presumed intent. ${ }^{107}$ Nor does Frankfurter stop with values which approach a constitutional level. Collective bargaining is such a dominant statutory policy that it is implicit in all related statutes. Thus, in the famous "overtime on overtime" case, he protested: "The presupposition of the Act was that .... the traditional process of collective bargaining was not to be disturbed where it existed."108 Again, a veteran's right to re-employment under the Selective Service Act was qualified by the union's right to give superseniority to union officers. "[I]t would be an undue restriction of the process of collective bargaining (without compensating gain to the veteran) to forbid changes in collective bargaining arrangements which secure a fixed tenure for union chairmen ...."109 The words of the statute may be bent also to avoid multiple penalties or other results which Frankfurter deems unduly harsh. ${ }^{110}$ These "presuppositions of legislative draftsmanship" are but additional fictions through which the Court functions as a coordinate law and policy maker. Frankfurter reads into the statute considerations which may never have occurred to the legislature. To speak of presumed intent beclouds the process, for the Court attempts no objective guess as to what Congress would have thought, had it thought. What Frankfurter says is that these values or policies are so basic, so integral a part of our social and legal pattern, that Congress cannot deny or destroy them without thinking. The Court will protect these values at least until Congress has given them the deliberate consideration which is evidenced by explicit statutory words. The Court does not block Congress; it only checks its thoughtlessness.

The central theme in Frankfurter's statutory construction is the search for purpose-the policy which Congress has chosen. In labor legislation, as in all legislation, this task can be treacherous, for the purposes may easily be

105. 316 U.S. 517, 521 (1942). See also 10 East 40th Street Bldg., Inc. v. Callus, 325 U.S. 578 (1945). The whole group of preemption cases implicitly involve this same problem, for the exclusion of the states depends upon the presumed intent of Congress. However, Frankfurter has not been so consistent in those cases. See text at note 154 infra.

106. Steele v. Louisville \& N. Ry., 323 U.S. 192 (1944). However, he would not carry this principle so far as to hold an employer liable under the Wagner Act for the union's abusive use of its closed shop contract. See Wallace Corp. v. NLRB, 323 U.S. 248, 257 (1944) (dissenting opinion by Jackson); Colgate-Palmolive-Peet Co. v. NLRB, 338 U.S. 355 (1949).

107. Graham v. Brotherhood of Locomotive Firemen, 338 U.S. 232 (1949).

108. Bay Ridge Operating Co. v. Aaron, 334 U.S. 446, 487 (1948) (dissenting opinion).

109. Aeronautical Lodge 727 v. Campbell, 337 U.S. 521, 529 (1949).

1.10. See United States v. Universal C.I.T. Credit Corp., 344 U.S. 218, 222 (1952) (continuing violation of FLSA does not constitute separate criminal offense for each day); Brooklyn Sav. Bank v. O'Neil, 324 U.S. 697, 719 (1945) (dissenting opinion by Stone, C.J.). But see United States v. Sullivan, 332 U.S. 689, 705 (1948) (dissenting opinion). 
misstated ${ }^{111}$ or imagined. ${ }^{112}$ Moreover, labor legislation has certain characteristics which make the search for purpose particularly treacherous. First, labor legislation commonly does not have a single purpose-it has a complex of purposes, none of which is carried to its logical limits. Frankfurter's opinions frequently ignore this complexity in favor of a single-minded search. In Brooks v. $N L R B$, the employer refused to continue bargaining with a certified union which had been directly repudiated by the employees without any encouragement from the employer..$^{113}$ Two policies of the statute collided: the freedom of employees to choose their bargaining representative and the stability of bargaining relationships. The statute did not draw the line of balance. Frankfurter ignored this conflict and found a simple, all-inclusive purpose: "The underlying purpose of this statute is industrial peace. To allow employers to rely on employees' rights in refusing to bargain with the formally designated union is not conducive to that end, it is inimical to it."114 The same pattern of reasoning underlies his dissent in Elgin, J. \& E. Ry. v. Burley. ${ }^{115}$ The union had settled certain grievances for back pay with the employer, but the individuals to whom the pay was owing sued the employer; they claimed the union had no authority to make a binding settlement. Frankfurter argued that the purpose of the Railway Labor Act was to provide a process of negotiation between unions and employers for the amicable settlement of disputes. Lack of authority in the union to make a binding settlement hindered this purpose. The majority, however, found that Congress did not intend to carry this single purpose to the limits of its logic. It did not intend "to submerge wholly the individual and minority interests... in the collective interest and agency."110 It had a qualifying purpose of "preserving the individual workman's right to have a voice ... in the settlement of claims arising out of his employment."117

111. See, e.g., United States v. Carbone, 327 U.S. 633 (1946). Union officers had been indicted under the Kickback Act for requiring employees on government projects to pay "permit fees" and then pocketing the money. The majority defined the statutory purpose as the prevention of underpayment of wages by employers and dismissed the indictment. Frankfurter, dissenting, defined the purpose to be "to protect forays against wages derived from federal funds." Id. at 644.

112. In Mastro Plastics Corp. v. NLRB, 350 U.S. 270, 289 (1956), Frankfurter, in dissent, reinforced his conclusion that the loss of status provision in $\S 8(\mathrm{~d})$ of Taft-Hartley applied to unfair labor practice strikers who struck during the term of the contract by taking "judicial notice" that "Congress may have set a very high value on peaceful adjustment." Id. at 297. He thus found an implied purpose to discourage economic self-help where legal remedies were available-a rather startling innovation that is difficult to square with other provisions of the statute.

113. 348 U.S. 96 (1954).

114. Id. at 103.

115. 325 U.S. 711, 749 (1945), modified on rehearing, 327 U.S. 661 (1946).

116. Id. at 733 .

117. Id. at 741. Frankfurter's opinion in United States v. Hutcheson, 312 U.S. 219 (1941), represents the extreme in stating broadly the legislative purpose and then following it to its logical conclusion without any acknowledgement that Congress may have had a less ambitious goal. 
A second and most significant characteristic of labor statutes is that they deal with an area where conflicting passions are deep, economic interests great and political forces strong. This greatly aggravates the difficulties in defining the purposes or in reconciling the cross-purposes imbedded in the statute. Legislation in the area is often possible only because it is skillfully ambiguous in not resolving the clash of interests. Frankfurter vividly describes this process in tracing the legislative history of the Clayton Act and concludes, "talk about the legislative intent as a means of construing legislation is simply repeating an empty formula. The Supreme Court had to find meaning where Congress had done its best to conceal meaning."118 In this respect, labor legislation bears a resemblance to collective agreements. It may dispose of the most difficult problems with ambiguous provisions which only postpone settlement. In collective bargaining, these problems may ultimately be thrown to an arbitrator to resolve; Congress may similarly push its problems to the courts. ${ }^{119}$ This may account for the extended litigation on certain sections of Taft-Hartley, particularly sections 8(d) and 304. Interpretation of such sections is not furthered by searching for the touchstone of purpose; the Court must often decide where Congress refused. ${ }^{120}$

In addition, the emotional and political climate in which labor legislation is born often leads to unusually poor draftsmanship. The judicial floundering in section 301 reveals the boggy wasteland resulting from congressional failure to recognize the difficult legal problems involved. The whole history of the Taft-Hartley Act is replete with examples of legal misconceptions on the part of those who were patching together the statute. Frankfurter, in his dissent in Mastro Plastics Corp. v. NLRB, displays the dangers inherent in reading such statutes too closely. ${ }^{121}$ He falls into the trap of assuming that Congress understood fully and precisely the existing law and that it would include no unnecessary or duplicating words. ${ }^{122}$ This assumption denies political reality

118. Frankfurter \& Greene, The Labor Injunction 145 (1930). Speaking of the decisions under the Clayton Act, Frankfurter says significantly: "Statutory construction in doubtful cases, in the last analysis, is a choice among competing policies as starting points for reasoning." Id. at 169.

119. A clear example of legislative irresolution is the failure to make any provision for multiple employer bargaining. See Truck Drivers Union v. NLRB, 231 F.2d 110 (2d Cir. 1956), rev'd, 353 U.S. 87 (1957). The legislative history suggests that since no explicit agreement could be reached, the solution was postponed; but time only increased the political heat around industry-wide bargaining. Finally, the Court had to decide a basic policy issue which may vitally affect the future character of our collective bargaining structure.

120. Congress may shift the problems to an administrative agency as well as to the courts. Where statutory interpretation is involved, Frankfurter has often given decisive weight to interpretations by the NLRB. See, e.g., NLRB v. Coca-Cola Bottling Co., 350 U.S. 264 (1956) ; NLRB v. Highland Park Mfg. Co., 341 U.S. 322, 326 (1951) (dissenting opinion). However, neither the Wage-Hour Administrator nor the Social Security Board has fared so well. See Social Security Bd. v. Nierotko, 327 U.S. 358 (1946) ; Addison v. Holly Hill Fruit Products, Inc., 322 U.S. 607 (1944).

121. 350 U.S. 270, 289 (1956).

122. Frankfurter's reasoning seems to assume that NLRB v. Sands Mfg. Co., 306 U.S. 332 (1939), made all economic strikes during the term of the contract wholly unprotected 
and diverts attention from the difficulty of giving meaning to what Congress has done.

Another characteristic of labor legislation, one vitally affecting the function of the courts, is its heavy inertia to change. For over fifty years, Congress has refused to decide whether unions should be subject to the antitrust laws. Whatever the Court decides, as in Duplex ${ }^{123}$ or Hutcheson, ${ }^{124}$ is allowed to stand. In twenty years, only one substantial statute dealing with labor-management relations has been enacted-the Taft-Hartley Act. In ten years, this act has revealed ambiguities which require resolution of basic policies, but Congress has failed to clarify. Jurisdictional disputes, "hot cargo" clauses, the "ally doctrine," union shop in the construction industry and organizational picketing-these are but a few problems that cry out for legislative answers; still, Congress does nothing.

This legislative paralysis forces on the Court the burden of molding outmoded and makeshift statutes to present needs. The Court cannot shrug off all responsibility for the practical wisdom of its decision with the casual attitude that if the result is bad Congress can change it. No matter which way Hutcheson had been decided, congressional action was unlikely. The wisdom of that decision and its economic impact are at least in part the Court's responsibility. But Frankfurter denies that the Court can or should assume such responsibility. ${ }^{125}$

Blindness to the political reality of legislative inertia leads to decisions like Guss v. Utah Labor Relations Bd.126 Statutory language and a measure of legislative history supported the holding that the states were excluded from

activity so that the Board had no power to order reinstatement and that this was so clear Congress would not waste words to crystallize the rule. He further assumes that NLRB v. Fansteel Metallurgical Corp., 306 U.S. 240 (1939), did not bar the Board from ordering reinstatement of employees discharged for violating the act or for other misconduct, if the employer had been guilty of an antecedent unfair labor practice and the Board found that reinstatement would effectuate the purposes of the act. Valid as this assumption may be, there is serious reason to doubt whether the drafters of the statute had so precisely understood the law. See Cox, The Right to Engage in Concerted Activities, 26 Ind. L.J. 319, 324 (1951).

123. Duplex Printing Press Co. v. Deering, 254 U.S. 443 (1921).

124. United States v. Hutcheson, 312 U.S. 219 (1941).

125. During the last term the Court was twice faced with the question whether the

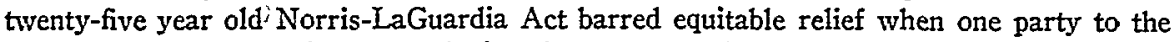
collective agreement refused to submit grievances to arbitration. He agreed that the employer could enjoin a union which ignored a statutory arbitration process. Brotherhood of R.R. Trainmen v. Chicago R. \& I.R.R., 353 U.S. 30 (1957). But he insisted that a union could not enjoin an employer who ignored a contractual arbitration process. Textile Workers Union v. Lincoln Mills, 353 U.S. 448, 460 (1957) (dissenting opinion). A clear recognition of responsibility for the practical result might have prevented such a distribution. Similarly, in Mastro Plastics Corp. v. NLRB, 350 U.S. 270, 289 (1956), if Frankfurter in his dissent had looked to the result, he might have hesitated to hold that an unfair labor practice charge with its delays and limited effectiveness was an adequate substitute for economic measures of self-help.

126. 353 U.S. 1 (1957). 
regulating even though the Board had refused to exercise jurisdiction. The drafters of Taft-Hartley had hoped that the states would follow their leadership and perhaps intended to prod them into line. However, this purpose did not find fulfillment. Although the "no man's land" problem became painfully evident, Congress stood silent. The NLRB, the state boards and the courts began to evolve tolerably workable solutions to fill the vacuum. The Supreme Court, destroying all of this in Guss, said, "Congress is free to change the situation at will."127 But practically, Congress will not do so. After six months, no action is yet in sight; conduct which violates both state and federal law goes wholly untouched. ${ }^{128}$ Had the Court upheld the power of the state instead of resurrecting a dead purpose, no violence would have been done to the statute; the democratic process would have suffered no derogation, and a year of disruption of state labor law would have been avoided. ${ }^{129}$

These characteristics of labor legislation impose on the courts a heavy responsibility which Frankfurter's whole articulate judicial philosophy rejects as improper for judges and the judicial process. Ideally, he is right; however, little is gained by deploring the defects of the legislative branch or by insisting on "fit legislation." Ultimately, the courts must decide, using whatever incomplete and awkward statutes have been provided. This does not mean that judges should depart on frolics of their own. The core of their function is, as Frankfurter has rightly emphasized, not to make policy but to construe and implement legislative policy, and the very character of labor legislation accentuates the need for a constant consciousness of self-subordination. Frankfurter's contextual method of interpretation, his accentuation of historical perspective and his deliberate judicial humility provide the essentials for the difficult task. He is handicapped only by his inability to admit the reality of an unwanted responsibility.

\section{JUdicial Self-Protection}

The constitutional principle of separation of powers contains two distinct policies-one, the prevention of dangerous concentration of power, the other, the allocation of functions to appropriate branches. To Frankfurter, the Court's function in allocation is clear. In his concurring opinion in the Steel Seizure case,

127. Id. at 11 .

128. Even the more prosaic principles of interpretation should have given pause. The claimed congressional purpose was national uniformity, but the decision brought a curious uniformity whereby conduct prohibited by both federal and state laws goes unrestrained by either. Can the Court so cavalierly dismiss "budgetary reasons" as irrelevant, when historically Congress has used control of the purse strings as a device of policy making? The Board's jurisdictional policy based on leaving broader areas of control to the states was known to Congress and was accepted as the basis for its appropriation. To ignore all this is not to implement but to frustrate the legislative will.

129. Compare with this the Court's action in the Buffalo Linen case. NLRB v. Truck Drivers Union, 353 U.S. 87 (1957), reversing 231 F.2d 110 (2d Cir. 1956). The policy choice there was on the side of preserving the existing system of multiple employer bargaining and confirming the right of employers to counteract whipsawing by sympathetic lockouts. 
he asserts that "the judiciary may ... have to intervene in determining where authority lies as between the democratic forces in our scheme of government" when a contest arises between them. ${ }^{130} \mathrm{He}$ admits in passing that the President's power may be enlarged by congressional grant or contracted by congressional prohibition. But he does not suggest the Court's conclusion if the two political branches should agree to combine their power in one or the other branch. ${ }^{131}$ Going no further than the case required, he rules that where Congress clearly prohibits seizure the President cannot seize and that the Court can enforce the congressional command by enjoining the executive. ${ }^{\mathbf{1 3 2}}$

Allocation of functions has at its roots the problem of determining the areas of competence of each branch. Although Frankfurter is reluctant to limit or deny the competence of the political branches, he does not shrink from doubting the competence of the judicial branch. The most appropriate function of the Court, he feels, is to protect itself from tasks which are not appropriate for judicial determination.

Two of Frankfurter's most controversial opinions carry overtones of such judicial self-protection. In The Labor Injunction, Frankfurter forcefully demonstrated that by determining the legality of union conduct, courts would be making rules to govern the struggle between employers and workers "for their respective shares in the goods of the world and in their much more subtle rivalry for power in the conduct of industry."133 Concerted action, in its manifold forms and purposes, raises "bristling issues of policy" concerning the cost of economic contest.134 "Primarily, this is the task of legislatures."135 This statement echoed Brandeis's dissent in Duplex when he said:

"The conditions developed in industry may be such that those engaged in it cannot continue their struggle without danger to the community. But it is not for judges to determine whether such conditions exist, nor is it their function to set the limits of permissible contest and to declare the duties which the new situation demands. This is the function of the legislature . . . "130

In short, such policy making was not an appropriate judicial function. The Norris-LaGuardia Act was conceived by Frankfurter as a legislative declaration of policy and as a definition of the permissible limits of concerted action. ${ }^{137}$

130. Youngstown Sheet \& Tube Co. v. Sawyer, 343 U.S. 579, 597 (1952).

131. Frankfurter explicitly recognizes the "hazards of concentrated power" but then falls into unhelpful phrasemaking - "the Framers, however, did not make the judiciary the overseer of our government"-and embarks on a discursive sermon on judicial humility. Id. at 593-94.

132. He found the congressional prohibition implicit in the wording and legislative history of the Taft-Hartley provisions concerning national emergency strikes, and also found that prohibition was not qualified by the Defense Production Act of 1950. Id. at $599,607$.

133. Frankfurter \& Greene, The Labor Injunction 203 (1930).

134. Id. at 204.

135. Id. at 205.

136. Duplex Printing Co. v. Deering, 254 U.S. 443, 488 (1921).

137. See Frankfurter \& Greene, The Labor InJunction 215-20 (1930). 
The Court, in United States $v$. Hutcheson, was again pressed to become a policy maker under the guise of enforcing the Sherman Act. ${ }^{138}$ Congress had provided no guide. Apex Hosiery Co. v. Leader, decided the year before, initiated new standards, but they threatened to revive the common-law concepts of restraint of trade which in labor cases had cloaked judicial policy-making ; ${ }^{.139}$ and Thurman Arnold, as Assistant Attorney General, had mounted his Sherman Act charger for a crusade against "unreasonable restraints" by unions for "illegitimate objectives."140 Frankfurter's decision was an act of judicial self-protection saving the Court from having thrust upon it the legislative function of making national labor policy.

A variation of the same theme runs through Frankfurter's dissent in Textile Workers Union v. Lincoln Mills. ${ }^{141}$ Here, he states his premise explicitly: "[T] he Court has deemed itself peculiarly qualified, with due regard to the contrary judgment of Congress, to determine what is meet and fit for the exercise of 'judicial power' as authorized by the Constitution." 142 Congress declared that collective agreements should be enforceable in the federal courts, but it left all of the difficult problems unanswered. The Court was asked to fashion a "whole industrial code" or "federal common law of labor contracts" with no guides but "judicial inventiveness."143 Federal interpretations of contracts would eventually collide with state interpretations, but Congress gave no hint how this clash should be resolved. The Court had further to create a whole structure of procedures and standards to enforce arbitration awards without any direction as to the application of the Arbitration Act. In short, Congress failed to meet its responsibility and cast the burden of lawmaking on the Court. At some point, the Court is entitled to rule that legislating is for Congress and that the judicial branch should not be saddled with functions which are not within its sphere of competence. For Frankfurter, this point was reached: ${ }^{144}$ " [A] refusal by the Justices to perform a function

138. 312 U.S. 219 (1941).

139. 310 U.S. 469 (1940).

140. After Apex and before Hutcheson, Arnold had described the types of union activity which he intended to prosecute as including "(1) Unreasonable restraints designed to prevent the use of cheaper material, improved equipment, or more efficient methods . . . (2) ... to compel the hiring of useless and unnecessary labor . . (3) . . . to enforce systems of graft and corruption ... (4) ... to enforce illegally fixed prices . . (5) . . . to destroy an established and legitimate system of collective bargaining." N.Y. Times, Nov. 20,1939 , p. 1, col. 4. These goals inrolved problems bristling with policy far more thorny than any which Frankfurter sought to remove from the courts by the Norris-LaGuardia Act.

141. 353 U.S. 448,460 (1957).

142. Id. at $464-65$.

143. Id. at $465-66$.

144. Frankfurter makes the Court's task appear much more onerous than it is. First, the industrial code has already been largely fashioned by both state and federal courts over a period of forty years, all without legislative guidance. The Supreme Court itself has already contributed substantially. See NLRB v. Lion Oil Co., 352 U.S. 282 (1957); Mastro Plastics Corp. v. NLRB, 350 U.S. 270 (1956) ; NLRB v. Rockaway News Supply Co., 
imposed upon them by Congress because of the non-judicial nature of that function" was justified. . $^{148}$

In neither of these cases did Frankfurter build a constitutional wall of separation; he did not state that Congress could not constitutionally impose these burdens on the Court. 140 What he did say was that at least the Court can refuse to assume these duties until Congress has thoroughly considered the problems and clearly determined that they are for the courts. ${ }^{147} \mathrm{This}$, in a sense, was a remand to Congress for reconsideration of the problems which the Court had found.

\section{The Decline of Federalisar}

One of the essential functions of the Court, Frankfurter has declared, is "striking the balance between the respective spheres of federal and state power."148 Where powers are distributed between the center and constituent units by a written constitution, conflicts as to the distribution of power "become legal issues to be resolved by a judicial and not a political tribunal"; the Court becomes the "inevitable mechanism of a federal state."149

If the Court is to act as an arbiter of the federal system, it must play a dual role. It must protect the nation from disintegration by state power; and it must protect the states from being smothered by national power. In a highly integrated economy subject to extensive government control, these roles con-

345 U.S. 71 (1953) ; Elgin, J. \& E. Ry. v. Burley, 325 U.S. 711 (1945) ; J. I. Case Co. v. NLRB, 321 U.S. 332 (1944) ; NLRB v. Sands Mfg. Co., 306 U.S. 332 (1939). In some of these cases, Frankfurter himself had theorized about the nature of collective agreements or interpreted their terms. Second, resolution of the clash of federal and state power is left no more unresolved here than elsewhere in Taft-Hartley, and the correlation of the two is probably not as difficult, for substantial uniformity is a practical possibility, and the state courts can follow federal law. Third, a less rigid approach to statutory interpretation could have made the Federal Arbitration Act applicable. See, e.g., Local 205, United Elec. Workers v. General Elec. Corp., 233 F.2d 85 (1st Cir. 1956). Frankfurter rebels at a job which thousands of other judges have been doing for years. But see Bickel \& Wellington, Legislative Purpose and the Judicial Process: The Lincoln Mills Case, 71 Harv. L. Rev. 1 (1957).

145. 353 U.S. at 464.

146. Although Frankfurter in Lincoln Mills finds $\$ 301$ unconstitutional for want of a federal question, he concedes that if Congress had clearly declared that federal substantive law was to apply, this constitutional obstacle would have been overcome. In spite of his strong language, he does not carry through to an explicit statement that the section unconstitutionally burdens the Court because of its vagueness.

147. Frankfurter recognizes that in the Fair Labor Standards Act Congress left to the Court the problem of marking out the boundaries of the statute without any helpful guides. 10 East 40th Street Bldg., Inc. v. Callus, 325 U.S. 578 (1945). However, since he sees this as arbitrating between state and federal power, it imposes no inappropriate function on the Court.

148. Frankfurter, Some Observations on the Nature of the Judicial Process of Supreme Court Litigation, 98 Procerdings, Amrrican Philosophical Soctety 233, 236 (1954), reprinted in OF LAW AND MEN 31, 38.

149. Frankfurter, The Supreme Court of the United States, 14 Encyclopaedra of THE Social Sciences 474, 475 (1934), reprinted in Law and Politics 21, 23. 
flict, and accommodation must be made. In spite of his words, Frankfurter gives the Court but a supporting role in making the accommodation and leaves ultimate control in the hands of Congress.

In Polish Nat'l Alliance v. NLRB, he declared it the duty of the Court to protect the states from "absorption of legislative power by the United States over every activity."150 However, what affects commerce "the Constitution entrusts primarily and very largely to Congress, subject to the electorate." 151 The Court can determine only whether Congress has "exceeded limits allowable in reason," whether the activities are "related to commerce merely by gossamer threads and not by solid ties."152 These words make reasonably clear that the Court provides no practical bar to the reach of congressional power. The only effective check is the political check. ${ }^{\mathbf{1 5 3}}$

The difficult problem in labor law, however, is not the reach of federal power but the survival of state power. The question is not whether Congress can grant or deny power to the states, but whether it has done so. Theoretically, the problem is one of statutory interpretation, but Frankfurter's conception that the Court has a special responsibility to mediate between state and nation gives him a greater sense of freedom. Since Congress is most often stubbornly silent or deliberately obtuse, the result he reaches is strongly colored by his conception of the proper relations between the state and federal governments.

In meeting these problems, Frankfurter is ambiguous. On the one hand, he conceives of the Court as a protector of the national interests and is fond of quoting Holmes's statement:

"I do not think the United States would come to an end if we lost our power to declare an Act of Congress void. I do think the Union would be imperiled if we could not make that declaration as to the laws of the several states. For one in my place sees how often a local policy prevails with those who are not trained to national views and how often action is taken that embodies what the Commerce Clause was meant to end."154

On the other hand, he echoes the view of his second idol, Brandeis, who vigorously opposed concentrations of power and championed the freedom of states to meet their special needs and provide laboratories for social experi-

150. 322 U.S. 643,650 (1944).

151. Ibid.

152. Ibid.

153. Compare Frankfurter's statement in New York v. United States, 326 U.S. 572, 581-82 (1946), suggesting that a state claim of immunity from federal taxation "raises questions not wholly unlike provisions of the Constitution, such as that of Art. IV, \& 4 guaranteeing States a republican form of government, . . . which this Court has deemed not within its duty to adjudicate."

154. Holmres, Collected Legal Papers 295-96 (1920), quoted in Frankfurter, John Marshall and the Judicial Function, $69 \mathrm{HARv}$. L. REv. 217, 219 (1955), reprinted in OF LAw and Men 3, 6; Frankfurter, The Supreme Court of the United States, 14 ENcyclopaedia of the Social Sciences 474, 475 (1934), reprinted in Law and Politics 21, 23; Frankfurter, Mr. Justice Holmes, 21 Dictionary of AMr. BrograpHy 417, 423 (Supp. One, 1944), reprinted in OF LaW AND MEN 158, 173. 
ment. Frankfurter's use of this value in interpreting statutes has already been described. ${ }^{165}$ His opinions in the preemption cases have wavered under the tug and haul of these two deeply held beliefs.

In the earlier preemption cases, Frankfurter vigorously protested against erosion of state power by implications from the Wagner Act. In Hill v. Florida, he defended the state's right to enjoin a union from functioning until it had complied with the state licensing statute. ${ }^{156}$ In Bethlehem Steel Co. v. New York State Labor Relations Bd., he affirmed the power of the National Board to cede jurisdiction to state boards. ${ }^{157}$ Finally, he asserted the right of Wisconsin to enforce compulsory arbitration in local utilities despite provisions in Taft-Hartley requiring the employer to bargain, affirming the right to strike and curtailing national emergency strikes. ${ }^{158}$ Through all these decisions ran the recurring theme most forcefully expressed in the Bethlehem Steel case:

"Congress needs no help from generous judicial implications to achieve the supersession of State authority. To construe federal legislation so as not needlessly to forbid preexisting State authority is to respect our federal system. Any indulgence in construction should be in favor of the States, because Congress can speak with drastic clarity whenever it chooses to assure full federal authority, completely displacing the States."169

The shift in the Court's approach to the preemption cases was marked by Garner v. Teamsters Union, ${ }^{100}$ and in this decision Frankfurter joined. For him too, it marked the end of attempts to preserve the state's power to regulate labor conflicts. In Garner, the state was wholly excluded from all regulation of peaceful picketing-a matter traditionally subject to local control. The state power was destroyed not by any explicit statutory words or legislative history but by an implication drawn from congressional prohibition of certain types of picketing. Prohibition of some picketing implied that states should not prohibit any other-a rather generous judicial implication to achieve supersession of state authority. ${ }^{161}$ Frankfurter not only remained silent in

155. See text at notes 90,133 supra.

156. 325 U.S. 538 (1945). Where a New York statute compelled a union of federal postal employees to admit Negroes, he dismissed the preemption problem as "to unsubstantial to require consideration." Railway Mail Ass'n v. Corsi, 326 U.S. 88, 98 (1945).

157. 330 U.S. 767 (1947). See also Algoma Plywood \& Veneer Co. v. Wisconsin Employment Relations Bd., 336 U.S. 301 (1949), upholding the right of the state under the Wagner Act to condition union security clauses on a two-thirds vote of all employees. However, Frankfurter refused to approve the Michigan strike vote law because it was to be enforced against the nationwide Chrysler Corporation and provided for a vote by only those employees in the bargaining unit in Michigan. UAW v. O'Brien, 339 U.S. 454 (1950).

158. Amalgamated Ass'n of Street Employees v. Wisconsin Employment Relations Bd., 340 U.S. 383 (1951).

159. 330 U.S. at 780. For similar expressions in nonlabor cases, see Rice v. Sante Fe Elevator Corp., 331 U.S. 218, 241 (1947) ; Cloverleaf Butter Co. v. Patterson, 315 U.S. 148, 178 (1942). But see California v. Zook, 336 U.S. 725 (1949).

160. 346 U.S. 485 (1953).

161. Id. at $499-500$. 
Garner, he adopted its language and logic in Weber v. Anheuser-Busch, Inc. ${ }^{102}$ The fire of his opinions in Hill v. Florida and Bethlehem Steel Co. v. New York State Labor Relations Bd. was gone. Congress did not need to "speak with drastic clarity," for it had "sufficiently expressed its purpose to bring it within federal oversight." 163 His concern was to protect the federal authority from any actual or potential conflict with state power. Finally, in his subdued dissent in UMW v. Arkansas Oak Flooring Co., he hinted at his problem of reconciling the positions of Holmes and Brandeis:

"Decisions ultimately depend on judgment in balancing overriding considerations making for the requirement of an exclusive nationwide regime in a particular field of legal control and respect for the allowable area within which the forty-eight States may enforce their diverse notions of policy."164

The culmination was Frankfurter's joinder in the Guss decision-a final reduction of state power over labor controversies to the constitutional de minimis. It is difficult to believe that either the Eightieth Congress or the Eighty-fifth Congress intended such centralization of control. The only surmise can be that Frankfurter, the once stout defender of federalism in labor relations, has now concluded that the complicated structure of TaftHartley places on the Court an intolerable burden of marking the lines between state and federal power. Stripping the states may prod Congress into making more explicit that which it intends to exclude. Ultimately, the problem is one of policy to be decided by Congress.

\section{The Court and Collective Bargaining}

Mr. Justice Frankfurter's preoccupation with the role of the Court prevents any clear distillation of his views on collective bargaining. In American Sash \& Door, he upheld the power of the states to prohibit all forms of union security, but in Railway Employes' Dep't, AFL v. Hanson, ${ }^{105}$ he affirmed the power of Congress to prohibit enforcement of the same state laws against railroad employees. The "hospitable scope" given to the Norris-LaGuardia Act in Hutcheson failed to encompass the subsequent injunction cases coming to the Court until the late date of Lincoln Mills. ${ }^{160}$ Such seeming inconsistencies demonstrate that any pretense of drawing from his opinion a pattern of views on collective bargaining is hazardous. Whatever pattern is discoverable is at best rudimentary, for concern with larger concepts has blocked full development.

162. 348 U.S. 468 (1955). He need not have gone so far, for the plaintiff's complaint in the state court had alleged a violation of $\$ \S(A),(B)$ and (D) of $\S \$(b)(4)$, and the Board had never passed on whether the conduct came within the first two subsections. He seems to imply that conduct protected by $\S 7$ from employer interference is also protected from state action-a position difficult to reconcile with his reasoning in Hill $v$. Florida.

163. Id. at 481 .

164. 351 U.S. 62,76 (1956).

165. 351 U.S. 225 (1956).

166. See text at note 19 supra. 
Frankfurter is a deep believer in the process of free collective bargaining, ${ }^{167}$ and this belief is fed by three converging theories. He sometimes emphasizes the Holmesian theory that combination of labor through unions is a natural and essential corollary of combination of capital through the corporation, which equalizes bargaining power between the two. ${ }^{188}$ Collective bargaining is the competitive system at work in the labor market. At other times, he echoes the Brandeis theory of diffusion of power through creating a system of "industrial self-government" by the employer and union which reduces the necessity for concentrated power in the state. Unexpressed in his opinions is his earliest theory that collective bargaining is a part of the democratic process through which workers participate in the direction of industry. ${ }^{169}$ Frankfurter has not integrated these three theories into any coordinated concept, but in his opinions the Brandeis theory dominates.

The "industrial self-government" concept leads Frankfurter to insist that the structures and rules developed through collective bargaining not be disrupted-that private government be allowed to govern. This tendency was most marked in the "portal to portal" and "overtime on overtime" dissents. "No time is a good time needlessly to sap the principle of collective bargaining or to disturb harmonious and fruitful relations between employers and employees brought about by collective bargaining."170 He protested vigorously against these decisions as "heedless of long-standing and socially desirable collective agreements." 171 In Aeronautical Industrial Lodge v. Campbell, ${ }^{172}$ he was not content with finding that the collective agreement did not discriminate against veterans by giving superseniority to union officers. He went beyond to justify such seniority agreements by showing their contribution to the bargaining process from which the veterans benefited.

The same hostility to legal intervention in this autonomous system brought forth his outburst against judicial enforcement of collective agreements in Textile Workers v. Lincoln Mills. "[T] he meaning of collective bargaining for labor does not remotely derive from reliance on the sanction of litigation in the courts. ... [J] udicial intervention is ill-suited to the special characteristics of the arbitration process in labor disputes . ..."173 Any rule developed

167. However, in Packard Motor Car Co. v. NLRB, 330 U.S. 485 (1947), he would have reverse'd the Board's holding that foremen were entitled to protection in organizing and bargaining collectively. The Wagner Act, he believed, was not intended to protect them. In NLRB v. E. C. Atkins \& Co., 331 U.S. 398 (1947), he would also have reversed the Board's certification as representative of plant guards a union which also represented production workers.

168. See AFL v. American Sash \& Door Co., 335 U.S. 538, 542, 545 (1949).

169. See text at note 9 supra.

170. Bay Ridge Operating Co. v. Aaron, 334 U.S. 446, 477 (1948).

171. Id. at 478. But compare Walling v. Harnischfeger Corp., 325 U.S. 427 (1.945), where Frankfurter did not allow the existence of a collective agreement to excuse undercutting FLSA standards. See also Bartels v. Birmingham, 332 U.S. 126 (1947).

172. 337 U.S. 521 (1949).

173. 353 U.S. at $462-63$. 
by the courts "is more likely to discombobulate than to compose."174 $\mathrm{He}$ manifests no recognition that compelling arbitration in contrast to direct legal enforcement of the contract avoids the necessity of judicial intervention on the merits, that it is a device to make the autonomous system internally responsible. ${ }^{175}$

Although he believes in collective bargaining, it is not clear that he considers the right to strike an inseparable part of the process. In Lion Oil, he spoke of the strike only as "a conventional factor in the collective-bargaining process."176 In $U M W$, he characterized the process of fixing terms and conditions of employment in the seized mines as one of collective bargaining, just as if the mines were in the hands of a receiver. ${ }^{177}$ The fact that workers in the seized mines could not strike was not even worth mentioning. Most telling is his dissent supporting the Wisconsin compulsory arbitration statute which not only barred strikes but prohibited the arbitrator from making an award which would "infringe upon the right of the employer to manage his business." He found in these provisions no serious incompatibility with collective bargaining as conceived in the federal statute. ${ }^{178}$

In this industrial self-government, Frankfurter accentuates the power of the union over the workers-the individual is all but submerged in the collective entity. The union, of course, has exclusive power to negotiate collective agreements which prescribe the rules governing the terms and conditions of employment. The crux of the problem is in the rights the individual obtains under the agreement. Frankfurter assumes that the collective agreement creates legal rights in the individual which he can enforce in the state courts, and on this point the Court is apparently in agreement. ${ }^{179}$ This leaves, however, the crucial question whether the union can, without the consent of the individual, surrender such rights to the employer through the grievance procedure. In Elgin, $J$. \& E. Ry. v. Burley, the union settled back pay claims of a number of employees in return for prospective concessions by the employer. ${ }^{180}$ The individual employees then brought suit. The Court held that under the Railway Labor Act the union could not make a binding settlement without the consent of the individuals. Frankfurter wrote two acid dissents suggesting that the decision "undermines the very conception of a collective

174. Id. at 464.

175. However, less than three months earlier he had joined in an opinion upholding an injunction against a union which struck to obtain settlement of grievances instead of submitting them to the National Railroad Adjustment Board with its interminable delays. Brotherhood of R.R. Trainmen v. Chicago R. \& I.R.R., 353 U.S. 30 (1957).

176. NLRB v. Lion Oil Co., 352 U.S. 282, 298 (1957) (concurring in part).

177. United States v. UMW, 330 U.S. 258, 320 (1947).

178. Amalgamated Ass'n of Street Employees v. Wisconsin Employment Relations Bd., 340 U.S. 383, 399-410 (1951).

179. See Association of Westinghouse Salaried Employees v. Westinghouse Elec. Corp., 348 U.S. 437,460 (1955).

180. 325 U.S. 711 (1945), modified on rehearing, 327 U.S. 661 (1946). 
agreement" and "reintroduces destructive individualism."181 The core of his dissent was that the bargaining structure developed by the parties would be disrupted. On rehearing, he cited as evidence the protest evoked by the first decision from all the major labor organizations. The Court's decision, he declared, "generally undermined the basis for all collective bargaining in regard to grievances" and "created havoc in the railroad world."182

Admittedly, unions strongly prefer the maximum control over those they. represent, and management frequently prefers to deal with those who have unqualified power. That collective bargaining requires such absolutism in disposing of rights created by the agreement does not follow, nor did Congress in enacting the Railway Labor Act necessarily intend so wholly to submerge the individual. Even at the expense of collective convenience, Congress may have sought to preserve some status for the individual. As the majority pointed out, the act made a clear distinction between disputes over the formation of contracts and disputes concerning the interpretation of existing agreements. Individual rights to confer with management, to be notified personally of hearings and to appear in person were explicitly provided. Frankfurter ignored all of these and, in the name of efficiency and orderliness in collective bargaining, would place the individual at the mercy of the collective entity.

Frankfurter would not leave the union wholly unchecked, however; he would enforce the Steele doctrine that unions must not exercise their power in an arbitrary way against some minority interests. ${ }^{183}$ Bargaining representatives are "in what amounts to a fiduciary position" and they "owe a judicially enforceable duty of fairness to all components of the working force." 184 This is, to Frankfurter, a broad principle. While he recognizes the difficulty of application- "conflict between majority and minority interests is a commonplace in the whole collective bargaining process"185 - he gives no suggestion of what tests he will apply or the mood in which he will weigh. The union's action represents a form of majority will reconciling conflicting values and interests in economic and business affairs, an area in which Frankfurter has often proclaimed judicial incompetence. If he carries over the attitudes with which he decides the parallel problems of substantive due process, the noble words will be little more than empty promises to all except racial minorities. If he recognizes that this private government lacks many of the political or procedural protections which add reliability to majority rule, he may search

181. 325 U.S. at 758.

182. 327 U.S. at 674 .

183. Steele v. Louisville \& N. Ry., 323 U.S. 192 (1944). Although he has written only one leading opinion in the series of cases following this decision, Aeronatitical Industrial Lodge v. Campbell, 337 U.S. 521 (1949), he has taken every opportunity to emphasize its impact. Thus, he joined in Mr. Justice Jackson's dissent in Trailmobile Co. v. Whirls, 331 U.S. 40, 62 (1947), based on the doctrine. See also Bay Ridge Operating Co. v. Aaron, 334 U.S. 446, 493 n.10 (1948) ; AFL v. American Sash \& Door Co., 335 U.S. 538, 546 (1949).

184. Pennsylvania R.R. v. Rychlik, 77 Sup. Ct. 421, 430-31 (1957).

185. Id. at 431. 
more critically for signs of unfairness. But this approach will inject him into the bargaining relationship and may require him to make the very kind of judgments he has so consistently rejected.

Frankfurter has never recognized that protecting the individual's right to his grievance is an aspect of protecting against unfairness. Contract provisions may be fair on their face yet be used as subtle instruments of oppression by manipulative grievance settlements. ${ }^{186}$ The Steele doctrine standing alone merely drives discrimination into the labyrinth of grievance handling where discovery is impossible. Only if an individual can insist that the agreement be enforced according to its terms does he have some hope of protecting himself from arbitrary use of power. Frankfurter has, in administrative proceedings, recognized that requiring authority to be exercised in accordance with rules laid down in advance is one of the basic safeguards against arbitrariness. ${ }^{187}$ Where power is exercised by a collective entity such as a union, demanding adherence to expressed rules-here the contract-has special justification in protecting against unfairness.

Most marked is Frankfurter's idealization of the Railway Labor Act, which he characterizes as "an instrument of industrial government for railroading, by the industry itself, through the concentrated agencies of railroad executives and the railroad unions." $188 \mathrm{He}$ repeatedly recalls that "the railroads and the railroad unions between them wrote the Railway Labor Act of 1926 and Congress formally enacted their agreement."189 To Frankfurter, "the dominant inference . . . is the exclusion of the courts from this process of collaborative self-government."190 The industry should be allowed to govern itself without judicial intervention.

The extent of his judicial hands-off attitude is exemplified in two opinions. In Order of $R y$. Conductors $v$. Szon, the Conductors and the Trainmen claimed that all disputes concerning yardmasters should be heard by the first division of the Adjustment Board, on which they each had representatives. ${ }^{101}$ The Railroad Yardmasters had failed to obtain a seat on any division of the Board; they claimed that these disputes should be heard by the fourth division, and the carriers joined in that claim. Since each division is made up of an equal number of union and carrier representatives, both were deadlocked by tie votes on the jurisdictional issue, and no grievance concerning Yardmasters could be processed. Faced by this stalemate, the Conductors sought a declaratory judgment as to which division of the Board had been granted jurisdiction

186. In many situations, the individuals or minorities singled out for unfair treatment cannot be grouped so as to make possible discrimination in writing the contracts. The greatest opportunity for disguised unfairness is in the arbitrary administration of proper provisions.

187. See, e.g., his joinder in Jackson's dissent in SEC v. Chenery Corp., 332 U.S. 194, 209 (1947).

188. Pennsylvania R.R. v. Rychlik, 77 Sup. Ct. 421, 431 (1957).

189. Railway Employees, AFL v. Hanson, 351 U.S. 225, 240 (1956).

190. Pennsylvania R.R. v. Rychlik, 77 Sup. Ct. 421, 430 (1957).

191. 329 U.S. 520 (1947). 
by the statute. Mr. Justice Frankfurter contended that since explicit command for judicial review was lacking, the dispute should be left to the mediatory machinery of the act. Even though that machinery was ineffective and the operation of the act had stagnated, the courts should not intrude to interpret the jurisdictional provisions of the statute.

Frankfurter's unwillingness to intervene is further emphasized by his opinion in the recent Rychlik case. ${ }^{192}$ An employee had joined the United Railroad Operating Crafts-UROC-a union competing with the old-line brotherhoods. The Trainmen, which had a union shop, demanded his discharge because he did not belong to a union "national in scope" as prescribed by the statute. His discharge was upheld by the System Board of Adjustment, composed of two representatives each from the Trainmen and the carrier, which determined that UROC was not "national in scope." Frankfurter insisted that the courts had no jurisdiction to review. "The determination of the System Board on the merits is not open to judicial review, even on so-called legal questions. . . . Right or wrong, a court has no jurisdiction to review what the System Board did."193

In short, this industrial self-government, created by Congress with powers and duties statutorily defined by Congress, is legally responsible to no one to stay within its statutory powers or procedures. Delegated power, in part supplanting judicial enforcement of individual rights, is left vagrant without legal dikes to confine it within its channels. The only legal check is the limited protection of the Steele doctrine.

That Frankfurter, at times most insistent that administrative agencies comply strictly with their statutory grants, would give such unsupervised power to the Adjustment Board is surprising. Neither the Board's make-up nor its performance has earned it special judicial toleration. It consists of persons chosen and paid by those who are often parties to the proceedings. Neither the unions nor the carriers have evidenced concern for individual or minority rights, nor have they demonstrated great responsibility for society or even the well-being of the industry. ${ }^{104}$ Cases like Slocum and Whitehouse reveal them making a shell game of the Board procedures. ${ }^{195}$ With an assist from Rychlik,

192. Pennsylvania R.R. v. Rychlik, 77 Sup. Ct. 421 (1957).

193. Id. at 431 .

194. For critical discussion of the National Railroad Adjustment Board, see Senate Committee on the Judiciary, Administrative Procedure in Govermment Agencies, S. Doc. No. 10, 77th Cong., 1st Sess., pt. IV (1941) ; Northrup \& Kahn, Railroad Grievance Machinery: A Critical Analysis-I and II, 5 IND. \& LAB. REL. REv. 365,540 (1952); Rose, The Railway Labor Act: The Union Shop and Impartial Tribunals, 42 A.B.A.J. 35 (1956); Comment, Railroad Labor Disputes and the National Railroad Adjustment Board, 18 U. CIII. L. Rev. 303 (1950).

195. In Slocum v. Delaware, L. \& W.R.R., 339 U.S. 239 (1950), the Railroad Telegraphers and the Railway Clerks both claimed certain yard jobs. The employer assigned the jobs to Clerks, and the Telegraphers filed a back pay claim invoking the NRAB. The employer, naming both unions as defendants, sought a declaratory judgment in a state court as to which union was entitled to the jobs. The Court, Frankfurter concurring, held 
they have choked off the only serious challenge to their ingrown craft separatism. Is it possible that Frankfurter has so often repeated that the railroad is a state within a state that he has been misled by metaphor into a misplaced economic federalism?

\section{ConCLUSION}

Professor Frankfurter has left an indelible mark on our labor law and collective bargaining. For more than twenty years before ascending the bench, he helped shape the law by which he should judge. Concurrently, he helped shape the judicial philosophy-the philosophy of Holmes, Brandeis and Cardozo-which has dominated his tenure on the Court. When he donned the robe, both of these frontiers had been largely won; the more difficult task of occupation and development remained.

Mr. Justice Frankfurter has left few deep imprints in labor law with the exception of Hutcheson, Phelps Dodge and the railroad cases. His attitude toward administrative tribunals indirectly influenced the substantive law by giving a wide measure of freedom to the NLRB in finding the facts, interpreting the statute and fixing the remedies. If his contribution to labor law has been modest, it is because his conception of the creative function of the Court is modest. He does not seek to define the role of unions and collective bargaining in a democratic society; he seeks instead to define the role of the Court in a democratic society.

His preoccupation with the role of the Court embodies a heavy residue of his own unhappy experiences in the minimum wage cases. He knows first hand the danger of willful judges who write their individual preferences into law. He would circumscribe the function of the Court to inhibit such judicial libertines in the future. Thus, he seeks eternal standards to control the Court -standards commanding obedience because they are based on fundamental principles of a democratic society. These principles derive from an unqualified reliance on the political process to resolve disputes where values conflict. The right to govern belongs solely to the elected legislature; for an oligarchic Court to set itself against the legislature or even act in its stead is a contradiction of democracy and politically indecent. The argument is reinforced by decrying the

that exclusive jurisdiction was in the Board and dismissed the suit. The same two unions were involved in the same kind of dispute in Whitehouse v. Illinois Cent. R.R., 349 U.S. 366 (1955). The employer again assigned the jobs to Clerks, and the Telegraphers again claimed back pay. The employer, learning from Slocum, prepared to go to the Board. However, it was notified by the Clerks that if the Telegraphers won and it gave them the jobs, the Clerks would file a claim. The employer sought to enjoin the Board from proceeding until the Clerks had been notified and made parties to the proceeding so that any award would be binding on both unions. Frankfurter, writing for the Court, denied relief on the ground that since the award might be against the Telegraphers, there was no showing of injury. He seemed unconcerned that this was all part of an agreement between the Telegraphers and the Clerks not to intervene in each other's proceedings, but to pursue their claims independently-apparently to exploit the chance that both would get back pay awards from separate referees. 
practical competence of the Court to deal with problems which require adjustment of conflicting interests.

Mr. Justice Frankfurter's appeal to these basic principles creates a form of rigidity, for they do not suggest exceptions or variations. The rules for avoiding constitutional issues become absolutes to be followed with equal strictness in all situations. The Court's function in determining constitutionality is the same for laws limiting hours as for laws limiting speech. The judge's function in interpreting a National Labor Relations Act is no different from his function in interpreting a negotiable instruments law. Although Frankfurter at times recognizes that the greatness of Marshall rests on his meeting the special needs of his day, he would seem to seek standards to guide the Court at all times. To allow variations would be to undercut the principles on which judicial restraint is based and open the door to judicial willfulness.

Unfortunately, our political system falls short of perfect democracy. Our system functions satisfactorily only because we have developed practices, institutions and traditions to fill its gaps and patch its weaknesses. One of the institutions on which we rely to protect us against our self-destructiveness and to fill the legislative gaps is the Court. To shrink the functions of the Court by appeal to principles which have only a half-measure of reality may impede instead of further government's ability to meet the felt needs of society.

To measure a judge's role according to that which can be safely entrusted to puny men is to reduce the whole Court to a pageant acted by bit players. Neither the Constitution, our traditions nor our existing structure treats the Court so casually. Judicial humility does not demand asceticism but suggests that judges meet the responsibilities which the system of their day requires. 